San Jose State University

SJSU ScholarWorks

Faculty Publications, Biological Sciences

Biological Sciences

6-1-2011

\title{
Importance of Behavior and Morphological Traits for Controlling Body Temperature in Littorinid Snails
}

Luke Miller

Stanford University, luke.miller@sjsu.edu

Mark Denny

Stanford University

Follow this and additional works at: https://scholarworks.sjsu.edu/biol_pub

Part of the Biology Commons

\section{Recommended Citation}

Luke Miller and Mark Denny. "Importance of Behavior and Morphological Traits for Controlling Body Temperature in Littorinid Snails" The Biological Bulletin (2011): 209-223. https://doi.org/10.1086/ BBLv220n3p209

This Article is brought to you for free and open access by the Biological Sciences at SJSU ScholarWorks. It has been accepted for inclusion in Faculty Publications, Biological Sciences by an authorized administrator of SJSU ScholarWorks. For more information, please contact scholarworks@sjsu.edu. 
1 Running head: Littorinid temperature relations

3 The importance of behavior and morphological traits for controlling body temperature in littorinid snails

5

6

Luke P. Miller ${ }^{1, *}$ and Mark W. Denny

Hopkins Marine Station, Stanford University

Pacific Grove, CA 93950

10

$11{ }^{1}$ Current address: Marine Science Center, Northeastern University, 430 Nahant Rd, Nahant, MA,

12 USA 01908

$13 *$ email: contact@lukemiller.org

14

15 Keywords: thermal stress, shell color, shell shape, Littorina, Echinolittorina natalensis, heat-

16 budget model, intertidal zone, conduction, convection

17 


\section{Summary}

For organisms living in the intertidal zone, temperature is an important selective agent

20 that can shape species distributions and drive phenotypic variation among populations. Littorinid

21 snails, which occupy the upper limits of rocky shores and estuaries worldwide, often experience

22 extreme high temperatures and prolonged aerial emersion during low tides, yet their robust

23 physiology — coupled with morphological and behavioral traits—permits these gastropods to

24 persist and exert strong grazing control over algal communities. We use a mechanistic heat-

25 budget model to compare the effects of behavioral and morphological traits on the body

26 temperatures of five species of littorinid snails under natural weather conditions. Model

27 predictions and field experiments indicate that, for all five species, the relative contribution of

28 shell color or sculpturing to temperature regulation is small, on the order of $0.2-2{ }^{\circ} \mathrm{C}$, while

29 behavioral choices such as removing the foot from the substratum or reorienting the shell can

30 lower body temperatures by $2-4{ }^{\circ} \mathrm{C}$ on average. Temperatures in central California rarely

31 exceeded the thermal tolerance limits of the local littorinid species, but at sites where snails are

32 regularly exposed to extreme high temperatures, the functional significance of the tested traits

33 may be important. The mechanistic approach used here provides the ability to gauge the

34 importance of behavioral and morphological traits for controlling body temperature as species

35 approach their physiological thresholds. 
Introduction

Within the narrow band of habitat between the low and high tidemarks on seashores, the distributions of individual species and the structure of ecological communities are dictated by a variety of biotic and abiotic factors (Connell, 1961; Lewis, 1964; Connell, 1972; Paine, 1974; Dayton, 1975; Menge and Branch, 2001). Biological interactions such as

41 predation, competition, and facilitation play out on a background of constantly-shifting

42 environmental conditions driven primarily by the action of tides and waves (Stephenson and

43 Stephenson, 1972; Denny, 2006; Denny et al., 2009). Changes in important environmental

44 parameters such as light, temperature, and wave action can alter the suitability of the habitat for a 45 given species at both small and large spatial scales (Wethey, 2002; Denny et al., 2004; Harley, 46 2008). The capacity of organisms to persist under these varied environmental conditions is

47 mediated by the interaction of a suite of behavioral, morphological, and physiological traits.

Snails in the family Littorinidae are important herbivores in mid- and high-shore

49 intertidal communities around the world (McQuaid, 1996a, b; Reid, 1996), and often exert

50 control over macroalgal and microalgal communities (Castenholz, 1961; Hawkins and Hartnoll,

51 1983; Norton et al., 1990; Hidalgo et al., 2008). These snails can experience large swings in

52 temperature over the course of a single tide cycle and must often contend with multi-day aerial

53 emersion periods when they live above the high tide line (Vermeij, 1972; Cleland and

54 McMahon, 1986; McMahon, 1990; Judge et al., 2009; Marshall et al., 2010).

The importance of morphological and behavioral traits for managing body temperature has been demonstrated in many terrestrial ectotherms such as insects, reptiles, and gastropods

57 (Schmidt-Nielsen et al., 1971; Porter et al., 1973; Stevenson, 1985; Huey, 1991; Kingsolver, 58 1996; Kearney et al., 2009), and similar roles for morphological and behavioral variation have 
59 been hypothesized for littorinid snails and other intertidal gastropods. Variation in shell color

60 across geographic scales has been hypothesized to be a response to climatic conditions, with

61 dark-colored morphs inhabiting cooler sites, while light-colored morphs dominate warmer areas

62 (Markel, 1971; Vermeij, 1971b; Etter, 1988; McQuaid and Scherman, 1988; McQuaid, 1992;

63 Sergievsky, 1992; McQuaid, 1996a; Phifer-Rixey et al., 2008), as has been argued for terrestrial

64 gastropods (Jones, 1973; Heath, 1975; Heller, 1981). Shell shapes can vary from globular to

65 high-spired, which affects heating by absorption of shortwave radiation from the sun and

66 determines the internal volume of fluid that can be stored in the shell to withstand desiccation

67 (Vermeij, 1972, 1973; Chapman, 1995). In addition, the outer surface of the shell may be

68 smooth, or it may be sculptured, with ribs, ridges, and nodules that increase the surface area of

69 the shell (potentially increasing convective heat flux) without a concomitant increase in the

70 projected area of the shell that captures heat energy from the sun (Vermeij, 1973; Britton, 1995).

71 While these morphological traits may impact body temperature, there are additional selective

72 forces such as predation and wave action that may drive the variation in shell morphology

73 (Struhsaker, 1968; Johannesson, 1986; Seeley, 1986; Johannesson et al., 1993; Trussell, 74 1997b, 2002).

Mobile intertidal grazers often seek refuge from hot conditions in crevices or under algal canopies. In contrast, littorinids - which often exploit food resources on open rock faces where

77 thermal refuges are absent - may employ additional behavioral strategies to avoid stressful high

78 temperatures. As with terrestrial gastropods that must withstand prolonged unfavorable weather

79 conditions (Stearns, 1877; Machin, 1967; Schmidt-Nielsen et al., 1972), littorinid snails

80 commonly remove the foot from the substratum and anchor the shell using a dried mucus

81 holdfast (Wilson, 1929; Newell, 1958; Vermeij, 1971b; Garrity, 1984). For a gastropod sitting 
82 on a surface warmed by the sun, the large surface area of the foot allows for substantial

83 conductive heat exchange between the foot and substratum (Vermeij, 1971a; Denny and Harley,

84 2006). The ability to remove the foot from the substratum reduces this conductive heat flux,

85 keeping a snail several degrees cooler than the substratum (Schmidt-Nielsen et al., 1972;

86 Vermeij, 1973). Many littorinid snails can also re-orient the shell, lifting the aperture away from

87 the substratum, leaving only the outer lip of the shell aperture attached to the substratum with

88 dried mucus (Fig. 1A, B) (Denny, 1984). Thusly, reorienting the shell alters conductive and

89 convective heat flux, and may change the projected area absorbing heat from the sun.

90 The relative importance of these morphological and behavioral characteristics for

91 controlling body temperature can be estimated using a mechanistic heat-budget model (Porter

92 and Gates, 1969; Gates, 1980; O'Connor and Spotila, 1992; Porter and Kearney, 2009),

93 combining physical parameters of the organism with environmental data to estimate body

94 temperature through time. From a high-resolution decade-long weather data set from Hopkins

95 Marine Station, Pacific Grove, California (HMS), we create historical reconstructions of snail

96 body temperatures to examine the effects of these morphological and behavioral changes,

97 particularly during high-temperature aerial exposures. Specifically, we test four hypotheses: 1)

98 light colored shells remain cooler than dark shells, 2) shells with surface ornamentation remain

99 cooler than smooth shells, 3) removing the foot from the substratum lowers body temperature,

100 and 4) reorienting the shell up off the substratum lowers body temperature. We compare the

101 relative effectiveness of each trait for controlling body temperature during hot aerial exposures,

102 and their effects on body temperature across the range of environmental temperatures

103 experienced in the field. 
To facilitate the manipulation of individual morphological and behavioral parameters, we

106 developed heat-budget models for five species of littorinid snails (Figure 1C). The snails

107 included four of the five common rocky intertidal Littorina species from the temperate western

108 North American coastline: Littorina keenae Rosewater, L. scutulata Gould (both collected at

109 HMS), L. plena Gould (collected from Tatoosh Island, Washington, USA), and L. sitkana

110 Philippi (collected from San Juan Island, Washington, USA). The fifth common species on these

111 shores, L. subrotundata Carpenter (not used in this study), is morphologically similar to $L$.

112 sitkana, so model results for L. sitkana should be similar for L. subrotundata. The final species

113 used in this study, Echinolittorina natalensis (formerly Nodilittorina natalensis Philippi, see

114 Williams et al., 2003), collected from Cape Vidal in the Natal region on the east coast of South

115 Africa, provided an ornamented shell for comparison to the smooth-shelled L. scutulata and $L$.

116 plena. Of the species used in this study, L. sitkana tends to live in low- to mid-intertidal zones

117 (Boulding and Van Alstyne, 1993; Rochette and Dill, 2000), while the remaining species occupy

118 the mid- and high-intertidal zone (Harger, 1972; Stirling, 1982; Behrens Yamada, 1989, 1992;

119 Branch et al., 2002).

120 Heat-budget model

121 The heat-budget model estimates an organism's body temperature by balancing the heat

122 fluxes $(W)$ into and out of the body (see Gates, 1980; Campbell and Norman, 1998).

$$
W_{\mathrm{sw}} \pm W_{\text {conv }} \pm W_{\text {cond }} \pm W_{\text {evap }}+W_{\text {met }} \pm W_{\text {lw }}=W_{\text {stored }}
$$


125 convective heat exchange with the air, $W_{\text {conv }}$; conductive heat exchange with the substratum,

$126 W_{\text {cond }}$; heat lost or gained due to evaporation or condensation, $W_{\text {evap; }}$ metabolic heat production,

$127 W_{\text {met }}$; and long-wave radiative exchange between the organism and its surroundings, $W_{\text {lw. The }}$

128 sum of these fluxes equals heat energy stored in the organism, $W_{\text {stored }}$. Our model was modified

129 from a heat-budget model originally developed for the intertidal limpet Lottia gigantea (Denny

130 and Harley, 2006), calculating the same heat flux components as the limpet model, but adding in

131 a behavioral component by altering the area of conduction, surface area for convection, and

132 projected area facing the sun depending on the modeled shell orientation and foot position (see

133 below).

134 Because littorinid snails have a small mass and are uninsulated, we treat stored heat

135 energy, $W_{\text {stored, }}$ as negligible and set it equal to zero. Metabolic heat production and evaporative

136 heat flux for small littorinids are approximately $0.07 \%$ and $1 \%$ as large as the heat flux due to

137 short-wave radiation at midday, respectively (Newell, 1976; Kronberg, 1990; Miller, 2008).

138 Based on these estimates, we treat metabolic heat production and heat flux due to evaporation as

139 negligible terms in the model, and therefore remove $W_{\text {met }}$ and $W_{\text {evap }}$ from the model. The

140 simplified heat-budget model used for this study is

$$
W_{\mathrm{sw}} \pm W_{\text {conv }} \pm W_{\text {cond }} \pm W_{\mathrm{lw}}=0
$$

The methods used for the parameterization of the model are described in detail in Denny 143 and Harley (2006) and Miller (2008). We made empirical measurements on a pair of snail shells 144 from each species, except for L. plena, for which we only had a single shell. Projected area and 145 substratum contact area were measured using size-referenced digital images analyzed in Image-J 
146 (Rasband, 1997-2010), and surface area was similarly estimated from digital images using the

147 method of Johnsen and Widder (1999). To estimate the heat transfer coefficient of each shell, we

148 used silver casts of each shell to measure rates of convective heat exchange in a wind tunnel for

149 shells both sitting down on the substratum or rotated up onto the lip of shell, allowing us to

150 incorporate the effects of wind speed and shell orientation on the convective flux component of

151 the model. Short-wave absorptivity (i.e. color) was measured using shell fragments mounted in

152 an integrating sphere attached to a Li-Cor 1800 spectroradiometer (LI-COR Biosciences,

153 Lincoln, Nebraska, USA). The thickness of any mucus attachment was treated as negligible and

154 was not present in the model, so that heat flux was modeled as occurring directly between rock

155 and shell surfaces. The rate-limiting step in conductive heat flux is assumed to be between the

156 rock surface and the foot when the snail is crawling, while conduction from the rock surface

157 through the shell is assumed rate-limiting when the snail is withdrawn into the shell. Shell

158 thickness values are given as "conductive distance" in Table 1, with the greater conduction

159 distance through the lip of the shell reflected in the greater distance given when the shell is

160 elevated from the substratum. The snail body and any mantle water trapped in the shell are

161 assumed to be at a single temperature due to blood circulation.

162

163 Model verification

164 Temperature predictions from the model were ground-truthed against temperature 165 measurements of live snails and silver-epoxy-filled shells in the field and laboratory. Live $L$.

166 keenae were close in size to the modeled L. keenae shells were fitted with polyurethane-coated $1670.08 \mathrm{~mm}$ diameter thermocouple leads (Omega Engineering Inc., Stamford, Connecticut, USA) 168 inserted through a hole ground in the shell and covered with cyanoacrylate glue. The hole was 
169 positioned so that the thermocouple entered the main body whorl near ground level when the

170 shell sat down on the substratum, and was designed to put the thermocouple tip in contact with

171 the snail body when the snail was withdrawn into the shell. Measurements of body temperature

172 of a live L. keenae were carried out in a temperature-controlled wind tunnel (see Miller et al.,

173 2009) with the snail actively crawling or with the foot withdrawn into the shell. For field

174 measurements, we took each of the shells used for the size measurements described above, filled

175 the shells with thermally-conductive silver epoxy (two parts ground silver shavings, one part

176 epoxy by volume; Devcon 2 Ton Clear Epoxy, ITW Devcon, Danvers, Massachusetts, USA),

177 and fitted a $0.08 \mathrm{~mm}$ thermocouple into a hole drilled in the epoxy filling. We deployed these

178 shells on a high-shore granite rock at approximately $2.5 \mathrm{~m}$ above mean lower low water at HMS

179 during two warm periods in April and June 2007. In addition, we fit thermocouples into two live

180 L. keenae to be deployed in the field alongside the silver-epoxy-filled shells during the June

181 experiment. Temperatures were monitored at 1-minute intervals by a datalogger (23X, Campbell

182 Scientific Inc., Logan, Utah, USA) while concurrently monitoring air temperature (Viasala

183 HMP45C, Campbell Scientific Inc.), wind speed (Wind Sentry, R. M. Young Co., Traverse City,

184 Michigan, USA), and solar irradiance (LI-200SB, LI-COR Biosciences, Lincoln Nebraska, 185 USA). The field site was not submerged during high tide and thus represented a "worst-case 186 scenario" for snails on the shoreline.

187 Model comparisons

188 For long-term reconstructions of snail body temperatures in the field at HMS, we used a 18910 year record of weather and sea-state data from HMS, spanning August 1, 1999 through July 190 31, 2009. This data set included air temperature, solar irradiance, wind speed, tide height, 191 significant wave height, and water temperature, all measured or interpolated at 10 min intervals 
192 (Denny and Harley, 2006). After specifying the shore height, wave exposure, and shell 193 orientation for a model snail, the heat-budget model calculates a body temperature for each 10 194 min time step based on the co-occurring environmental conditions. When the tide height exceeds

195 the specified shore height, the snail body temperature is set equal to sea surface temperature, and 196 when the tide and waves recede below the modeled shore height, the snail heats or cools 197 according to the sum of the heat fluxes to and from the surrounding environment. The heat198 budget model was employed to analyze the effects of behavioral or morphological changes on 199 predicted body temperatures for the snail species under a variety of weather conditions. Because 200 the focus of the study was to examine the effects of these traits under a "worst-case" scenario, all 201 species were modeled resting on a horizontal surface $2.0 \mathrm{~m}$ above mean lower low water, a 202 height which is $0.4 \mathrm{~m}$ above the mean higher high water line at HMS and thus is only submerged 203 during spring tides or when large waves are present. The predicted temperatures for pairs of 204 snails of each species were generally within a fraction of a degree Celsius, and so we only report 205 results from a single representative shell of each species. The model was implemented in 206 MATLAB 7 (The Mathworks Inc., Natick, Massachussetts, USA). Analyses were carried out in 207 MATLAB and R 2.12.1 (2010).

208 Two behavioral manipulations were carried out with the model. First, the effect of 209 removing the foot from the substratum was simulated by changing the contact area of the snail 210 with the rock while leaving other parameters constant. The modeled snail either kept the foot in 211 contact with the rock constantly, or withdrew the foot into the shell after three hours of aerial 212 emersion, mimicking the behavior of snails that close the operculum as the rock surface becomes 213 dry. Second, the effect of reorienting the shell up onto the aperture lip was tested by using a 214 further-reduced value of contact area and simultaneously altering values for the projected area 
215 facing the sun and the surface area of the shell, as the aperture of the shell is exposed to the air

216 rather than being held against the substratum (see Table 1 for representative values for each

217 shell).

218 Effects of shell color on body temperature were tested by altering the short-wave

219 absorptivity of the shell ( $\alpha$, a dimensionless value) while leaving all other characteristics

220 constant. Four shell colors were compared, nominally referred to as "black" $(\alpha=0.85)$, "green"

$221(\alpha=0.82)$, "brown" $(\alpha=0.80)$, and "white" $(\alpha=0.67)$. Shell color differences were also

222 compared for snails over a range of substratum contact areas to illustrate the relative

223 contributions of color and conduction to the overall heat budget of the snail. Black and white $L$.

224 keenae were modeled with contact areas that scaled from full foot contact to having only the

225 outer lip of the shell glued to the substratum. Shell ornamentation comparisons were carried out

226 by comparing temperature predictions for L. scutulata and E. natalensis. These two high-spired

227 species grow to similar overall sizes, but E. natalensis has rows of nodules on the shell surface,

228 increasing the total surface area for convection while only slightly increasing the projected area

229 for absorbing solar irradiance. Both snails were modeled with a brown shell to remove effects of

230 color differences.

Effects of morphological and behavioral manipulations were compared by examining

232 predicted body temperatures. Maximum body temperature or body temperature differences

233 between model scenarios were calculated for the $10 \mathrm{yr}$ time series. Because the heat-budget

234 model is deterministic, we report calculated temperatures and standard deviations for the

235 temperatures rather than standard errors. 
In addition to the ten year hindcasts for HMS, we modeled body temperatures with

237 different foot and shell positions for L. scutulata at ten additional sites (Table 2) along the west

238 coast of North America between August 2007 and August 2009 to gauge the effects of these

239 behaviors at sites that might be more thermally stressful than HMS. Data for L. scutulata are

240 reported because it is found throughout the west coast of the US (Reid, 1996), although modeled

241 estimates of body temperatures for the other species at each site are very similar. Tide height,

242 water temperature, air temperature and wind speed data were obtained from tide monitoring

243 stations run by the U.S. National Oceanic and Atmospheric Administration's Center for

244 Operational Oceanographic Products and Services, available through an online database

245 (http://tidesandcurrents.noaa.gov/). When several hours or days of data were missing for a

246 station, water temperatures were filled in from the nearest oceanographic buoy available in the

247 NOAA database, while air temperature and wind speeds were obtained from the nearest weather

248 station available in the MesoWest database maintained by the Department of Atmospheric

249 Sciences at the University of Utah (http://mesowest.utah.edu/). Data for La Jolla, CA, were

250 obtained from the Scripps Institute of Oceanography

251 (http://meteora/ucsd.edu/weather/observations/sio-pier/dat/). Solar irradiance estimates for each

252 site were obtained from NOAA's National Environmental Satellite, Data, and Information

253 Service, which produces a map of satellite-derived hourly down-welling shortwave radiation for

254 North America, available through the Department of Atmospheric and Oceanic Science at the

255 University of Maryland (http://www.atmos.umd.edu/ srb/gcip/). All data were linearly

256 interpolated to a 10-minute period. Predictions for 15 December 2008 to 8 January 2009 were

257 discarded due to unavailable solar irradiance data. We predicted L. scutulata body temperatures

258 for a black snail either with the foot extended at all times, the foot withdrawn into the shell 
259 resting on the rock, or the foot withdrawn and the shell rotated up onto the edge of the shell lip.

260 Effects of wave surge were removed from the model due to uneven availability of data for the

261 sites. We used the granite substratum characteristics from HMS for all sites. Because the vertical

262 extent of the tide varies between sites, we modeled the snail at the high water mark for each site,

263 which represents a likely worst-case scenario for thermal stress.

264 Live snail color comparisons

265 To complement the heat-budget model predictions, a comparison of shell color effects on

266 body temperature was carried out with live L. keenae during a heat wave on May 14-16, 2008 at

267 HMS, when the air temperature exceeded 27,36 and $35^{\circ} \mathrm{C}$ respecitvely. Three pairs of similar-

268 sized L. keenae were collected from the field. The shell of one snail from each pair was naturally

269 black, the other, white. Shell length was within $0.2 \mathrm{~mm}$ and total mass was within $0.05 \mathrm{~g}$ for each

270 pair of snails. Maximum shell length was $13.25 \mathrm{~mm}$, minimum shell length was $11.13 \mathrm{~mm}$. A

$2710.08 \mathrm{~mm}$ diameter thermocouple wire, coated with a thin layer of polyurethane glue, was inserted

272 into a hole ground in the main body whorl of the shell. The hole in the shell was then covered in

273 cyanoacrylate glue to minimize evaporative water loss. Instrumented snails crawled normally in

274 aquaria for the $24 \mathrm{hrs}$ prior to deployment in the field. The snails were placed on a high-shore

275 granite rock at midnight, May 14, 2008. The rock was wetted with seawater and the snails were

276 allowed to crawl. As the rock dried, all snails withdrew the foot and glued the shell to the rock,

277 but kept the shell aperture down against the rock surface. A datalogger recorded body

278 temperatures once per minute for the subsequent $68 \mathrm{hr}$.

\section{Results}

280

Model parameters 
284 Behrens Yamada, S. 1989. Are direct developers more locally adapted than planktonic developers? Mar. Biol. 103: 403-411.

Behrens Yamada, S. 1992. Niche relationships in northeastern Pacific littorines. Pp. 281-291 in Proceedings of the Third International Symposium on Littorinid Biology, J. Grahame, P. J. Mill and D. G. Reid, eds. The Malacological Society of London.

Bock, C. E., and R. E. Johnson. 1967. The role of behavior in determining the intertidal zonation of Littorina planaxis Phillipi, 1847, and Littorina scutulata Gould, 1849. Veliger 10: 42-54.

Boulding, E. G., and K. L. Van Alstyne. 1993. Mechanisms of differential survival and growth of two species of Littorina on wave-exposed and on protected shores. J. Exp. Mar. Biol. Ecol. 169: 139-166.

Branch, G. M., C. L. Griffiths, M. L. Branch, and L. E. Beckley. 2002. Two Oceans: A Guide to the Marine Life of Southern Africa. David Philips Publishers, Cape Town.

Britton, J. C. 1995. The relationship between position on shore and shell ornamentation in two size-dependent morphotypes of Littorina striata, with an estimate of evaporative water loss in these morphotypes and in Melarhaphe neritoides. Hydrobiologia 309: 129-142.

Britton, J. C., and R. F. McMahon. 1986. The relationship between vertical distribution evaporative water loss rate behavior and some morphometric parameters in four species of rocky intertidal gastropods from Hong Kong. Pp. 1153-1171 in Proceedings of the Second International Marine Biological Workshop: The Marine Flora and Fauna of Hong Kong and Southern China, Hong Kong, 1986, B. Morton, ed. Hong Kong University Press, Hong Kong. 
Broekhuysen, G. J. 1940. A preliminary investigation of the importance of desiccation, temperature and salinity as factors controlling the vertical distribution of certain intertidal

Campbell, G. S., and J. M. Norman. 1998. An Introduction to Environmental Biophysics. marine gastropods in False Bay, South Africa. Trans. R. Soc. S. Afr. 28: 255-291. 783-794.

Chapman, M. G. 1995. Spatial patterns of shell shape of three species of co-existing Littorinid

Castenholz, R. W. 1961. Effect of grazing on marine littoral diatom populations. Ecology 42: snails in New South Wales, Australia. J. Molluscan Stud. 61: 141-162.

Chow, V. 1989. Intraspecific competition in a fluctuating population of Littorina plena Gould (Gastropoda: Prosobranchia). J. Exp. Mar. Biol. Ecol. 130: 147-165.

Cleland, J. D., and R. F. McMahon. 1986. Upper thermal limit of nine intertidal gastropod species from a Hong Kong rocky shore in relation to vertical distribution and desiccation associated with evaporative cooling. Pp. 1141-1152 in Proceedings of the Second International Marine Biological Workshop: The Marine Flora and Fauna of Hong Kong and Southern China, Hong Kong, 1986 B. Morton, ed. Hong Kong University Press, Hong Kong.

Clusella-Trullas, S., J. H. van Wyk, and J. R. Spotila. 2007. Thermal melanism in ectotherms. J. Therm. Biol. 32: 235-245.

Connell, J. H. 1961. Effects of competition, predation by Thais lapillus, and other factors on natural populations of the barnacle Balanus balanoides. Ecol. Monogr. 31: 61-104.

Connell, J. H. 1972. Community interactions on marine rocky intertidal shores. Annu. Rev. Ecol. Syst. 3: 169-192. 
Cook, L. M., and P. M. Freeman. 1986. Heating properties of morphs of the mangrove snail Littoraria pallescens. Biol. J. Linn. Soc. 29: 295-300.

Dayton, P. K. 1975. Experimental evaluation of ecological dominance in a rocky intertidal algal community. Ecol. Monogr. 45: 137-159.

Denny, M. W. 1984. Mechanical properties of pedal mucus and their consequences for gastropod structure and performance. Am. Zool. 24: 23-36.

Denny, M. W. 2006. Ocean waves, nearshore ecology, and natural selection. Aquat. Ecol. 40: 439-461.

Denny, M. W., and C. A. Blanchette. 2000. Hydrodynamics, shell shape, behavior and survivorship in the owl limpet Lottia gigantea. J. Exp. Biol. 203: 2623-2639.

Denny, M. W., T. L. Daniel, and M. A. R. Koehl. 1985. Mechanical limits to size in waveswept organisms. Ecol. Monogr. 55: 69-102.

Denny, M. W., and C. D. G. Harley. 2006. Hot limpets: predicting body temperature in a conductance-mediated thermal system. J. Exp. Biol. 209: 2409-2419.

Denny, M. W., B. Helmuth, G. Leonard, C. D. G. Harley, L. J. H. Hunt, and E. K. Nelson. 2004. Quantifying scale in ecology: lessons from a wave-swept shore. Ecol. Monogr. 74: 513-532.

Denny, M. W., L. J. H. Hunt, L. P. Miller, and C. D. G. Harley. 2009. On the prediction of extreme ecological events. Ecol. Monogr. 79: 397-421.

Etter, R. J. 1988. Physiological stress and color polymorphism in the intertidal snail Nucella lapillus. Evolution 42: 660-680.

Evans, F. 1961. Responses to disturbance of the periwinkle Littorina punctata (Gmelin) on a shore in Ghana. Proceedings of the Zoological Society of London 137: 393-402. 
Garrity, S. D. 1984. Some adaptations of gastropods to physical stress on a tropical rocky shore. Ecology 65: 559-574.

354 Gates, D. M. 1980. Biophysical Ecology. Springer-Verlag, New York, USA.

355 Harger, J. R. E. 1972. Competitive coexistence among intertidal invertebrates. Am. Sci. 60: 600-607.

Harley, C. D. G. 2008. Tidal dynamics, topographic orientation, and temperature-mediated mass mortalities on rocky shores. Mar. Ecol. Prog. Ser. 371: 37-46.

Harley, C. D. G., M. W. Denny, K. J. Mach, and L. P. Miller. 2009. Thermal stress and morphological adaptations in limpets. Funct. Ecol. 23: 292-301.

Hawkins, S. J., and R. G. Hartnoll. 1983. Grazing of intertidal algae by marine invertebrates. Oceanography and Marine Biology: an Annual Review 21: 195-282.

Heath, D. J. 1975. Colour, sunlight, and internal temperatures in the land-snail Cepaea nemoralis (L.). Oecologia 19: 29-38.

Heller, J. 1981. Visual versus climatic selection of shell banding in the landsnail Theba pisana in Israel. Journal of Zoology 194: 85-101.

\section{Helmuth, B., B. R. Broitman, C. A. Blanchette, S. E. Gilman, P. M. Halpin, C. D. G.} Harley, M. J. O'Donnell, G. E. Hofmann, B. A. Menge, and D. Strickland. 2006. Mosaic patterns of thermal stress in the rocky intertidal zone: implications for climate change. Ecol. Monogr. 76: 461-479.

\section{Helmuth, B., C. D. G. Harley, P. M. Halpin, M. O'Donnell, G. E. Hofmann, and C. A.} Blanchette. 2002. Climate change and latitudinal patterns of intertidal thermal stress. Science 298: 1015-1017. 
Hidalgo, F. J., F. N. Firstater, E. Fanjul, M. C. Bazterrica, B. J. Lomovasky, J. Tarazona, and O. O. Iribarne. 2008. Grazing effects of the periwinkle Echinolittorina peruviana at a central Peruvian high rocky intertidal. Helgol. Mar. Res. 62: S73-S83.

Huey, R. B. 1991. Physiological consequences of habitat selection. The American Naturalist 137: S91-S115.

Hughes, J. M., and P. B. Mather. 1986. Evidence for predation as a factor in determining shell color frequencies in a mangrove snail Littorina sp. (Prosobranchia: Littorinidae). Evolution 40: 68-77.

Johannesson, B. 1986. Shell morphology of Littorina saxatilis Olivi: the relative importance of physical factors and predation. J. Exp. Mar. Biol. Ecol. 102: 183-195.

Johannesson, K. 2003. Evolution in Littorina: ecology matters. J. Sea Res. 49: 107-117.

Johannesson, K., and A. Ekendahl. 2002. Selective predation favouring cryptic individuals of marine snails (Littorina). Biol. J. Linn. Soc. 76: 137-144.

Johannesson, K., B. Johannesson, and E. Rolán-Alvarez. 1993. Morphological differentiation and genetic cohesiveness over a microenvironmental gradient in the marine snail Littorina saxatilis. Evolution 47: 1770-1787.

Johnsen, S., and E. A. Widder. 1999. The physical basis of transparency in biological tissue: ultrastructure and the minimization of light scattering. J. Theor. Biol. 199: 181-198.

Jones, J. S. 1973. Ecological genetics and natural selection in mollusks. Science 182: 546-552.

Judge, M. L., R. Duell, L. Burriesci, and W. Moarsi. 2009. Life in the supralittoral fringe: microhabitat choice, mobility and growth in the tropical periwinkle Cenchritis (=Tectarius) muricatus (Linneaus, 1758). J. Exp. Mar. Biol. Ecol. 369: 148-154. 
Kearney, M., R. Shine, and W. P. Porter. 2009. The potential for behavioral thermoregulation to buffer "cold-blooded" animals against climate warming. Proc. Natl. Acad. Sci. U.S.A. 106: $3835-3840$.

Kingsolver, J. G. 1996. Experimental manipulation of wing pigment pattern and survival in western white butterflies. The American Naturalist 147: 296-306.

Kronberg, I. 1990. Heat production in Littorina saxatilis Olivi and Littorina neritoides L. (Gastropoda: Prosobranchia) during an experimental exposure to air. Helgol. Wiss. Meeresunters. 44: 125-134.

Lang, R. C., J. C. Britton, and T. Metz. 1998. What to do when there is nothing to do: The ecology of Jamaican intertidal Littorinidae (Gastropoda: Prosobranchia) in repose. Hydrobiologia 378: 161-185.

Lewis, J. R. 1964. Ecology of Rocky Shores. English Universities Press, London.

Machin, J. 1967. Structural adaptation for reducing water-loss in three species of terrestrial snail. Journal of Zoology 152: 55-65.

Manríquez, P. H., N. A. Lagos, M. E. Jara, and J. C. Castilla. 2009. Adaptive shell color plasticity during the early ontogeny of an intertidal keystone snail. Proc. Natl. Acad. Sci. U.S.A. 106: $16298-16303$.

Markel, R. P. 1971. Temperature relations in two species of tropical west American littorines. Ecology 52: 1126-1130.

Marshall, D. J., C. D. McQuaid, and G. A. Williams. 2010. Non-climatic thermal adaptation: implications for species' responses to climate warming. Biology Letters 6: 669-673.

McMahon, R. F. 1990. Thermal tolerance evaporative water loss air-water oxygen consumption and zonation of intertidal prosobranchs: a new synthesis. Hydrobiologia 193: 241-260. 
McMahon, R. F., and J. C. Britton. 1985. The relationship between vertical distribution, thermal tolerance, evaporative water loss rate, and behavior on emergence in six species of mangrove gastropods from Hong Kong. Pp. 563-582 in The Malacofauna of Hong Kong and Southern China. II, Vol. 1 and 2. Second International Workshop: Hong Kong, Hong Kong, Apr. 6-24, 1983., B. Morton and D. Dudgeon, eds. Hong Kong University Press, Hong Kong.

McMahon, R. F., and W. D. Russell-Hunter. 1977. Temperature relations of aerial and aquatic respiration in six littoral snails in relation to their vertical zonation. Biol. Bull. 152: 182198.

McQuaid, C. D. 1992. Stress on the high shore: a review of age-dependent causes of mortality in Nodilittorina knysnaensis and N. africana. Pp. 85-89 in Proceedings of the Third International Symposium on Littorinid Biology, J. Grahame, P. J. Mill and D. G. Reid, eds. The Malacological Society of London, London.

McQuaid, C. D. 1996a. Biology of the gastropod family Littorinidae. I. Evolutionary aspects. Oceanography and Marine Biology: an Annual Review 34: 233-262.

McQuaid, C. D. 1996b. Biology of the gastropod family Littorinidae. II. Role in the ecology of intertidal and shallow marine ecosystems. Oceanography and Marine Biology: an Annual Review 34: 263-302.

McQuaid, C. D., and P. A. Scherman. 1988. Thermal stress in a high shore intertidal environment: morphological and behavioural adaptations of the gastropod Littorina africana. Pp. 213-224 in Behavioral Adaptation to Intertidal Life, G. Chelazzi and M. Vannini, eds. Plenum Press, New York. 
441 Menge, B. A., and G. M. Branch. 2001. Rocky Intertidal Communities. Pp. 221-251 in Marine 442 Community Ecology, M. D. Bertness, S. D. Gaines and M. E. Hay, eds. Sinauer 443 Associates, Inc., Sunderland, Massachusetts.

444 Miller, L. P. 2008. Life on the edge: morphological and behavioral adaptations for survival on 445 wave-swept shores, PhD Thesis, Biology, Stanford University.

Miller, L. P., C. D. G. Harley, and M. W. Denny. 2009. The role of temperature and desiccation stress in limiting the local-scale distribution of the owl limpet, Lottia

Miller, S. L. 1974. Adaptive design of locomotion and foot form in prosobranch gastropods. $J$.

Miller, L. P., M. J. O'Donnell, and K. J. Mach. 2007. Dislodged but not dead: survivorship of a high intertidal snail following wave dislodgement. J. Mar. Biol. Assoc. U. K. 87: 735739. Exp. Mar. Biol. Ecol. 14: 99-156.

Mislan, K. A. S., D. S. Wethey, and B. Helmuth. 2009. When to worry about the weather: role of tidal cycle in determining patterns of risk in intertidal ecosystems. Global Change Biology 15: 3056-3065.

Muñoz, J. L. P., G. R. Finke, P. A. Camus, and F. Bozinovic. 2005. Thermoregulatory behavior, heat gain, and thermal tolerance in the periwinkle Echinolittorina peruviana in central Chile. Comparative Biochemistry and Physiology, Part A 142: 92-98.

Newell, G. E. 1958. The behaviour of Littorina littorea (L.) under natural conditions and its relation to position on the shore. J. Mar. Biol. Assoc. U. K. 37: 229-239.

462 Newell, R. C. 1976. Adaptations to intertidal life. Pp. 1-82 in Adaptation to Environment: Essays 463 on the Physiology of Marine Animals, R. C. Newell, ed. Butterworths, London, UK. 
Norton, T. A., S. J. Hawkins, N. L. Manley, G. A. Williams, and D. C. Watson. 1990. Scraping a living: a review of littorinid grazing. Hydrobiologia 193: 117-138.

O'Connor, M. P., and J. R. Spotila. 1992. Consider a spherical lizard: animals, models, and approximations. Am. Zool. 32: 179-193.

Ohgaki, S.-i. 1988. Rain and the distribution of Nodilittorina exigua (Dunker) (Gastropoda: Littorinidae). J. Exp. Mar. Biol. Ecol. 122: 213-223.

Paine, R. T. 1974. Intertidal community structure - experimental studies on relationship between a dominant competitor and its principal predator. Oecologia 15: 93-120.

Pardo, L. M., and L. E. Johnson. 2005. Explaining variation in life-history traits: growth rate, size, and fecundity in a marine snail across an environmental gradient lacking predators. Mar. Ecol. Prog. Ser. 296: 229-239.

Phifer-Rixey, M., M. Heckman, G. C. Trussell, and P. S. Schmidt. 2008. Maintenance of clinal variation for shell colour phenotype in the flat periwinkle Littorina obtusata. J. Evol. Biol. 21: 966-978.

Porter, W. P., and D. M. Gates. 1969. Thermodynamic equilibria of animals with environment. Ecol. Monogr. 39: 228-244.

Porter, W. P., and M. Kearney. 2009. Size, shape, and the thermal niche of endotherms. Proc. Natl. Acad. Sci. U.S.A. 106: 19666-19672.

Porter, W. P., J. W. Mitchell, W. A. Beckman, and C. B. DeWitt. 1973. Behavioral implications of mechanistic ecology: thermal and behavioral modeling of desert ecototherms and their microenvironment. Oecologia 13: 1-54.

R Development Core Team 2010. R: A language and environment for statistical computing. $R$ Foundation for Statistical Computing, Vienna, Austria. http://www.R-project.org/ 
Rasband, W. S. 1997-2010. ImageJ. U. S. National Institutes of Health, Bethesda, Maryland, USA. http://rsb.info.nih.gov/ij/

Reid, D. G. 1987. Natural selection for apostasy and crypsis acting on the shell color polymorphism of a mangrove snail, Littoraria filosa (Sowerby) (Gastropoda: Littorinidae). Biol. J. Linn. Soc. 30: 1-24.

Reid, D. G. 1996. Systematics and Evolution of Littorina. The Dorset Press, Dorchester, UK.

Reid, D. G. 2002. Morphological review and phylogenetic analysis of Nodilittorina (Gastropoda: Littorinidae). J. Molluscan Stud. 68: 259-281.

Reimchen, T. E. 1979. Substratum heterogeneity, crypsis, and colour polymorphism in an intertidal snail (Littorina mariae). Canadian Journal of Zoology 57: 1070-1085.

Rochette, R., and L. M. Dill. 2000. Mortality, behavior and the effects of predators on the intertidal distribution of littorinid gastropods. J. Exp. Mar. Biol. Ecol. 253: 165-191.

Schmidt-Nielsen, K., C. R. Taylor, and A. Shkolnik. 1971. Desert snails: problems of heat, water and food. J. Exp. Biol. 55: 385-398.

Schmidt-Nielsen, K., C. R. Taylor, and A. Shkolnik. 1972. Desert snails: Problems of survival. Pp. 1-13 in Comparative Physiology of Desert Animals, G. M. O. Maloiy, ed. Academic Press, London.

Seeley, R. H. 1986. Intense natural selection caused a rapid morphological transition in a living marine snail. Proc. Natl. Acad. Sci. U.S.A. 83: 6897-6901.

Sergievsky, S. O. 1992. A review of ecophysiological studies of the colour polymorphism of Littorina obtusata (L.) and L. saxatilis (Olivi) in the White Sea. Pp. 235-245 in Proceedings of the Third International Symposium on Littorinid biology, J. Grahame, P. J. Mill and D. G. Reid, eds. The Malacological Society of London, London. 
Sokolova, I. M., and H.-O. Pörtner. 2003. Metabolic plasticity and critical temperatures for aerobic scope in a eurythermal marine invertebrate (Littorina saxatilis, Gastropoda: Littorinidae) from different latitudes. J. Exp. Biol. 206: 195-207.

513 Somero, G. N. 2002. Thermal physiology and vertical zonation of intertidal animals: Optima, limits, and costs of living. Integr. Comp. Biol. 42: 780-789.

515 Stearns, R. E. C. 1877. On the vitality of certain land mollusks. Am. Nat. 11: 100-102.

516 Stephenson, T. A., and A. Stephenson. 1972. Life between tidemarks on rocky shores. W. H. Freeman and Company, San Francisco.

518 Stevenson, R. D. 1985. The relative importance of behavioral and physiological adjustments controlling body temperature in terrestrial ectotherms. The American Naturalist 126:

Stirling, H. P. 1982. The upper temperature tolerance of prosobranch gastropods of rocky shores at Hong Kong and Dar ES Salaam, Tanzania. J. Exp. Mar. Biol. Ecol. 63: 133-144.

Struhsaker, J. W. 1968. Selection mechanisms associated with intraspecific shell variation in Littorina picta (Prosobranchia: Mesogastropoda). Evolution 22: 459-480.

Tomanek, L. 2010. Variation in the heat shock response and its implication for predicting the effect of global climate change on species' biogeographical distribution ranges and metabolic costs. J. Exp. Biol. 213: 971-979.

Trussell, G. C. 1997a. Phenotypic plasticity in the foot size of an intertidal snail. Ecology 78: 1033-1048.

Trussell, G. C. 1997b. Phenotypic selection in an intertidal snail: Effects of a catastrophic storm. Mar. Ecol. Prog. Ser. 151: 73-79. 
Trussell, G. C. 2000. Predator-induced plasticity and morphological trade-offs in latitudinally separated populations of Littorina obtusata. Evol. Ecol. Res. 2: 803-822.

Trussell, G. C. 2002. Evidence of countergradient variation in the growth of an intertidal snail in response to water velocity. Mar. Ecol. Prog. Ser. 243: 123-131.

Trussell, G. C., and M. O. Nicklin. 2002. Cue sensitivity, inducible defense, and trade-offs in a marine snail. Ecology 83: 1635-1647.

Vermeij, G. J. 1971a. Substratum relationships of some tropical Pacific intertidal gastropods. Mar. Biol. 10: 345-320.

Vermeij, G. J. 1971b. Temperature relationships of some tropical Pacific intertidal gastropods. Mar. Biol. 10: 308-314.

Vermeij, G. J. 1972. Intraspecific shore level size gradients in intertidal mollusks. Ecology 53: 693-700.

Vermeij, G. J. 1973. Morphological patterns in high-intertidal gastropods: adaptive strategies and their limitations. Mar. Biol. 20: 319-346.

Wada, S., and A. Ito. 2000. Preliminary observation on "tip-lip" attachment in the periwinkle Nodilittorina radiata. Bull. Mar. Sci. Fish. Kochi Univ. 20: 15-24.

Wethey, D. S. 2002. Biogeography, competition, and microclimate: The barnacle Chthamalus fragilis in New England. Integr. Comp. Biol. 42: 872-880.

Williams, S. T., D. G. Reid, and D. T. J. Littlewood. 2003. A molecular phylogeny of the Littorininae (Gastropoda: Littorinidae): unequal evolutionary rates, morphological parallelism, and biogeography of the Southern Ocean. Molecular Phylogenetics and Evolution 28: 60-86. 
554 Wilson, D. P. 1929. A habit of the common periwinkle (Littorina littorea Linn). Nature 124: $555 \quad 443$.

556 
558 Table 1. L. keenae was the largest snail used, with a maximum shell length of $10.8 \mathrm{~mm}$ from the

559 spire tip to the outer edge of the aperture lip. L. plena was the smallest snail, at a maximum

560 length of $5.7 \mathrm{~mm}$. Parameters used for calculating heat exchange between the rock surface and

561 the snail shell, or between the sky and the snail shell, are the same as those given in Denny and

562 Harley (2006) and Miller (2008).

563 Model verification

564 The heat-budget model predicted temperatures for silver-epoxy-filled shells from all five

565 species and for live L. keenae deployed in the field that were typically within $1.5^{\circ} \mathrm{C}$ of the

566 measured temperatures at each time point, while predictions for the hottest $1 \%$ of time points

567 were within $0.64{ }^{\circ} \mathrm{C}$ of measured temperatures (Table 3, Figure 2). The largest deviations

568 between predicted and measured temperatures occurred during foggy conditions at night because

569 our weather records do not record the incidence of fog. The altered long-wave heat-flux during

570 foggy periods should keep snails slightly warmer than predicted by our model. Temperature

571 predictions for the live L. keenae measured in the temperature-controlled wind tunnel agreed

572 closely with measured temperatures. The difference between measured and predicted

573 temperatures was $0.18{ }^{\circ} \mathrm{C} \pm 0.27$ (mean $\pm \mathrm{SD}$ ) while the snail was actively crawling, and was

$5740.02{ }^{\circ} \mathrm{C} \pm 0.40$ when the foot was withdrawn and the shell rested on the substratum.

\section{Effect of foot position}

576 The effect of withdrawing the foot into the shell and leaving only portions of the shell in

577 contact with the substratum was estimated by calculating the average temperature difference

578 between the foot-out and foot-withdrawn positions during the hottest $1 \%$ of all 10 -minute time

579 periods in the $10 \mathrm{yr}$ dataset $(n=5260)$. Snails modeled with the foot withdrawn were $2.3-3.2$ 
$580{ }^{\circ} \mathrm{C}$ cooler on average during these hot periods than snails that kept the foot attached to the

581 substratum, with a maximum difference of $5.4{ }^{\circ} \mathrm{C}$ for the smallest species, L. plena (Figure 3A).

582 When the foot was left in contact with the surface, the maximum predicted temperature at HMS

583 for all five species was between 40.4 and $40.7^{\circ} \mathrm{C}$. When the foot was withdrawn into the shell

584 during low tide, the maximum temperature experienced by the five modeled species during the

$58510 \mathrm{yr}$ model run ranged from 38.4 to $39.0^{\circ} \mathrm{C}$. The smallest snail modeled, L. plena, stayed the

586 coolest, and the largest species, L. keenae, reached the highest temperatures. The daily maximum

587 body temperature for each day in the 10 year time series $(n=3652)$ was generally higher for a

588 snail with its foot in contact with the rock, as shown for L. keenae (Figure 4A).

589 Effect of shell position

590 Standing the shell on edge yielded body temperatures that were on average 1.5 to $2.3{ }^{\circ} \mathrm{C}$

591 cooler during the hottest $1 \%$ of time points when compared to the same shell sitting down against

592 the substratum with the foot withdrawn (Figure 3B). For all species, the maximum temperature

593 difference between the two shell orientations was between 2.2 and $3.5^{\circ} \mathrm{C}$. While snails in either

594 orientation generally start from similar body temperatures in the pre-dawn hours, the difference

595 in temperatures grows through the day and typically becomes largest during the hottest part of

596 the day. Maximum temperatures reached by snails with the shell elevated off the substratum

597 ranged from $36.9{ }^{\circ} \mathrm{C}$ (L. plena) to $37.8{ }^{\circ} \mathrm{C}$ (L. keenae). Daily maximum body temperature for

598 every day in the 10 year time series was higher for snails that left the shell on the substratum,

599 except during occasional cooler periods when the elevated shells became warmer (Figure 4B).

600 Latitudinal comparison 
602 temperatures near the edges of its latitudinal distribution (Figure 5), both in the north at Friday

603 Harbor, WA $\left(42.9^{\circ} \mathrm{C}, 6\right.$ days $\left.>40^{\circ} \mathrm{C}\right)$ and Toke Point, WA $\left(40.7^{\circ} \mathrm{C}, 2\right.$ days $\left.>40^{\circ} \mathrm{C}\right)$, and in the

604 south in Los Angeles $\left(41.9^{\circ} \mathrm{C}, 2\right.$ days $\left.>40{ }^{\circ} \mathrm{C}\right)$ and La Jolla, CA $\left(42.7^{\circ} \mathrm{C}, 4\right.$ days $\left.>40{ }^{\circ} \mathrm{C}\right)$. In all

605 cases, a snail with the foot in contact with the rock reached the highest temperatures, while

606 removing the foot from the rock reduced the predicted maximum temperature by $1.18 \pm 0.53{ }^{\circ} \mathrm{C}$

607 (mean $\pm \mathrm{SD}$ ), and elevating the shell reduced maximum temperature by an additional $1.56 \pm 0.34$

$608{ }^{\circ} \mathrm{C}$.

609 Effect of shell color

610 For black $v s$. white comparisons, the model predicted average temperature differences of

6110.38 to $0.54{ }^{\circ} \mathrm{C}$ during the hottest $1 \%$ of times in the data set, with maximal differences of $0.8{ }^{\circ} \mathrm{C}$

612 (Figure 3C). Black shells were always predicted to be warmer than white shells when exposed to

613 the sun, while brown and green shells fell closer to black shells. The magnitude of the

614 temperature difference between shell color morphs was influenced by conductive heat flux

615 through the shell or foot, and greater conductive flux with the rock tended to homogenize body

616 temperatures (Figure 6). At colder environmental temperatures, a similar pattern in temperature

617 differences between black and white shell color morphs was maintained. For daylight low tides

618 when air temperatures were less than $15^{\circ} \mathrm{C}$, black morphs of L. keenae were $0.44 \pm 0.2^{\circ} \mathrm{C}$

619 (mean $\pm 1 \mathrm{SD}$, for all seasons, $n=80,476$ time points) warmer than white morphs when snails

620 were modeled elevated off the substratum (Figure 7A), and for snails modeled with the foot

621 always in contact with the substratum, the average predicted difference between black and white

622 morphs was reduced to $0.03 \pm 0.03{ }^{\circ} \mathrm{C}$ across all seasons (Figure 7B). 
624 similar to those predicted by the model. Among the three pairs of snails, the average temperature 625 difference between live black and white snails was less than $0.5^{\circ} \mathrm{C}$ during daylight hours (Table

626 4). The maximal difference between black and white shells was $2.39^{\circ} \mathrm{C}$, though there were 627 periods during the day when the white shell in each pair was hotter than the black shell.

631 periods was minimal. The heat transfer coefficient was greater for the nodulose E. natalensis

632 shell compared to the smooth-shelled L. scutulata, but the convective flux difference was

633 greatest at high wind speeds (Figure 8A), which rarely occur during the hottest days (see Denny

634 and Harley, 2006, materials and methods for the calculation of the heat transfer coefficient). On

635 calm, hot days, the small difference in heat transfer coefficient resulted in an average predicted

636 body temperature for L. scutulata $0.2 \pm 0.3{ }^{\circ} \mathrm{C}($ mean $\pm \mathrm{SD}, n=5260)$ warmer than a similarly-

637 sized and identically-colored E. natalensis shell modeled in the same weather conditions (Figure 638 8B).

\section{Discussion}

640 Littorinid snails often occupy the highest reaches of the intertidal zone, remaining

641 exposed to terrestrial conditions for hours to days. As a result, these species may reach high body

642 temperatures when weather and ocean conditions combine to create hot low tide periods.

643 Although littorinids can move to refuges to avoid high temperatures and desiccation stress, this

644 study has focused on littorinid snails living on open rock faces, where they may be the only 
645 species exerting grazing control over algal communities (Norton et al., 1990; McQuaid, 1996b).

646 The behavioral and morphological traits of these species, combined with their physiological

647 tolerance to heat and desiccation stress, permits them to occupy these habitats and survive

648 extreme weather conditions.

649 Most rocky intertidal gastropods must keep their foot attached to the substratum to

650 maintain their position on the shore, but this comes at the expense of increasing conductive heat

651 flux between the foot and a potentially hot substratum (Denny and Harley, 2006). The propensity

652 for littorinid snails to anchor their shell to the rock with mucus and withdraw the foot into the

653 shell provides a reduction in body temperature not available to most other intertidal gastropods

654 (Vermeij, 1971a, 1973; McQuaid and Scherman, 1988), and results in body temperatures for the

655 five species studied here that can be $3-5^{\circ} \mathrm{C}$ lower than when the foot is left in contact with the

656 rock. Withdrawing the foot into the shell has the added benefit of allowing the snail to seal the

657 operculum, thereby reducing water loss (McMahon and Britton, 1985; Britton and McMahon,

658 1986). As a result, littorinid snails typically have very slow evaporative water loss rates,

659 permitting survival of multi-day aerial exposures (Broekhuysen, 1940; Cleland and McMahon,

660 1986; Britton, 1995; Marshall et al., 2010). The use of a mucus holdfast does, however,

661 introduce a trade-off in terms of stability and attachment strength relative to the snail foot

662 (Miller, 1974; Denny, 1984; Ohgaki, 1988), increasing the chance of dislodgement. However,

663 survival of dislodged snails is typically high and they are commonly able to navigate back to

664 their preferred high shore habitats (Evans, 1961; Bock and Johnson, 1967; Miller et al., 2007).

665 Reorienting the shell so that only the outer lip of the shell is in contact with the

666 substratum further enhances littorinid snails' ability to minimize body temperature on warm

667 days. Although we lack quantitative data on the frequency of this behavior in the field, the shell- 
668 lifting behavior has been observed in all five species discussed here (L. Miller, personal

669 observations), as well as in numerous other littorinid snail species (Garrity, 1984; Britton, 1995;

670 Lang et al., 1998; Wada and Ito, 2000). Lifting the shell from the substratum further reduces the

671 surface area in contact with the substratum over the initial reduction achieved by pulling the foot

672 into the shell (Table 1), but also changes other important heat flux components. The reoriented

673 shell exposes a greater surface area to the surrounding air, increasing the rate of convective heat

674 exchange, which cools a snail that is warmer than the air, as is often the case on hot days

675 (Marshall et al., 2010), while also lifting the shell higher into faster-flowing air in the boundary

676 layer over the rock. Together, the reduction in conduction and increase in convection help

677 minimize body temperature, as has been shown in many terrestrial organisms (Stevenson, 1985).

678 Changing shells' orientation could also change the projected area facing the sun, potentially

679 minimizing absorption of shortwave radiation. Although some species of littorinid snails have

680 been shown to orient parallel to the sun when resting against the substratum (Muñoz et al.,

681 2005), there is no evidence that the species studied here consistently orient the shell spire

682 towards the midday sun (Miller, 2008).

The role of shell morphology in avoiding high body temperatures is relatively small.

684 Within the range of shell colors tested, the reduction in body temperature created by having a

685 white versus a dark shell is on average less than $0.5^{\circ} \mathrm{C}$, both for model snails of all five species

686 and for live L. keenae. The complementary hypothesis - that dark shells should be advantageous

687 in cool conditions by helping to warm these ectothermic animals - also receives minimal support

688 (Jones, 1973; Phifer-Rixey et al., 2008). Due to the substantial influence of conductive heat flux

689 between the snail foot and the rock substratum, an actively grazing littorinid snail does not

690 deviate from the substratum temperature appreciably, so that differences in short-wave 
691 absorptivity between shell colors result in temperature differences of less than $0.5^{\circ} \mathrm{C}$ in the

692 model, while the range of reported temperature differences between color morphs of other

693 species of intertidal snails is on the order of $0-2{ }^{\circ} \mathrm{C}$ (Markel, 1971; Cook and Freeman, 1986;

694 Reid, 1987; Phifer-Rixey et al., 2008), with differences of $3-5{ }^{\circ} \mathrm{C}$ in some larger snails species

695 on certain substrata (Etter, 1988). The high thermal conductivity and heat capacity of seawater

696 effectively homogenizes temperatures in the intertidal zone during high tide and when waves

697 splash during rising and ebbing tides, removing any effect of shell color on body temperature

698 during these periods. Thus, while thermal melanism may be important for warming the body in

699 some terrestrial organisms (Kingsolver, 1996; Clusella-Trullas et al., 2007), the importance to

700 gastropods in intertidal systems is less clear. Differences in shell colors among intertidal snail

701 populations could be driven by other factors such as visual predation by crabs and fishes

702 (Reimchen, 1979; Hughes and Mather, 1986; Reid, 1987; Johannesson and Ekendahl, 2002;

703 Manríquez et al., 2009).

The functional significance of shell shape in intertidal snails has received substantial

705 attention. Shell shape and size influence drag forces imposed by waves during high tide (Denny

706 et al., 1985; Boulding and Van Alstyne, 1993; Trussell, 1997a; Denny and Blanchette, 2000;

707 Pardo and Johnson, 2005) determine the volume of fluid retained in the shell during emersion

708 (Vermeij, 1973; Britton and McMahon, 1986), and provide protection from predators (Seeley,

709 1986; Trussell, 2000; Trussell and Nicklin, 2002; Johannesson, 2003). The importance of shell

710 shape for mitigating stress due to exposure to extreme high temperatures in these small species is

711 less clear. We have shown that when comparing L. scutulata and E. natalensis, the addition of

712 nodules on the outer surface of E. natalensis shells produces a negligible reduction in body

713 temperature on hot days. These results mirror the minor contribution of shell sculpture to 
714 convective cooling found in intertidal limpet species (Harley et al., 2009). Additionally,

715 estimated temperatures for the globose, ribbed L. sitkana do not differ markedly from the other

716 high-spired species examined here. Despite the relatively small effect of shell shape and shell

717 sculpturing on body temperature in the temperate climate conditions used here, the trend within

718 tropical intertidal gastropods, and particularly littorinids, is generally towards increased

719 sculpturing and higher-spired shells at higher shore heights (Vermeij, 1973). The nodulose

720 littorinids such as E. natalensis are primarily found in tropical or sub-tropical regions, so the

721 importance of these characteristics to controlling body temperature may take on a greater

722 importance at low latitudes where the frequency of high temperature exposures is greater.

723 Though body temperature changes created by the behavioral choices and color

724 differences described here are only a few degrees, they may be sufficient to help littorinid snail

725 populations avoid substantial mortality due to thermal stress. The reported physiological thermal

726 tolerances of L. keenae and L. scutulata (> 42-44 ${ }^{\circ} \mathrm{C}$, Somero, 2002) exceed the body

727 temperatures predicted for snails in the field at HMS, but snails at other sites along the coast may

728 approach or exceed these temperature limits. The frequency and severity of thermal stress events

729 are driven by the timing of the tides and the coincidence of calm, warm weather conditions with

730 midday tides (Helmuth et al., 2002; Helmuth et al., 2006; Denny et al., 2009; Mislan et al.,

731 2009). Our model predicts that littorinids living throughout the species' latitudinal ranges could

732 occasionally experience prolonged aerial emersion at midday during weather conditions hot

733 enough to push body temperatures close to $42{ }^{\circ} \mathrm{C}$. Under these circumstances, the additive

734 benefits of removing the foot from the rock, reorienting the shell, and having lighter shell colors

735 could keep body temperatures several degrees below those lethal temperatures and help limit

736 sublethal temperature stress. Work on the physiology of related littorinid snails has shown that as 
737 temperatures approach lethal limits, there is often an attendant decrease in aerobic respiration,

738 increases in anaerobic metabolism, and eventual heart failure (McMahon and Russell-Hunter,

739 1977; Sokolova and Pörtner, 2003; Marshall et al., 2010), along with the added energetic cost

740 of repairing cellular-level damage through avenues such as heat shock protein expression

741 (Tomanek, 2010).

742 Although lighter shell colors help avoid temperature stress, the native snail populations in

743 many of the warmer sites on the west coast of North America highlighted here contain a

744 substantial fraction of dark-colored individuals (L. Miller, personal observations). All of the

745 Littorina species discussed here, except $L$. sitkana, have a pelagic larval dispersal phase (Reid,

746 1996, 2002), so that mixture among populations may counteract any selection for lighter shell

747 colors at hot sites. In sub-tropical and tropical habitats the role of shell color may be more

748 important, as evidenced by experiments with black-painted littorine snails in South Africa that

749 demonstrated that darker colors did result in acute thermally-induced mortality on hot days

750 (McQuaid, 1992). At sites with higher peak air and substratum temperatures, the small reduction

751 in body temperature created by a light colored shell may make the difference between survival

752 and death on hot days, especially after the more effective behavioral options have been

753 exhausted.

754 Based on the long-term weather records for our central California coast site, it appears

755 unlikely that acute high temperature exposures regularly cause significant mortality in Littorina

756 populations at HMS. However, when considered over the lifetime of an organism, the cumulative

757 benefits of the small temperature reductions afforded by the behavioral and morphological traits

758 examined here could be important for allowing littorinids to exploit high littoral habitats. Sub-

759 lethal temperatures will still incur metabolic costs that can be partially mitigated by having a 
760 lighter colored shell or minimizing conductive heat flux from a hot substratum. The attendant

761 reduction in desiccation stress provided by these traits may also help contribute to the success of

762 littorinids in the high intertidal zone (Chow, 1989). While these behaviors or shell morphologies

763 may have little effect on the occurrence of single-day thermal mortality events at HMS, on other

764 shores, particularly tropical shores and sites where mid-day low tides frequently coincide with

765 warm weather, these traits may be key in allowing littorinids to avoid thermally-induced

766 mortality.

\section{Acknowledgements}

768 We appreciate the help of Drs. C. D. G. Harley and K. Sink for providing access to snail shells

769 used in this study. C.J. Sorte, C. Matassa, S. Kent, and M. Doellman and two anonymous

770 reviewers provided useful suggestions for the manuscript. This work was supported by a NSF

771 grant OCE 9985946 to M. W. Denny, and an award from the Dr. Earl H. Meyers and Ethel M.

772 Myers Oceanographic and Marine Biology Trust to L. P. Miller. This is contribution number 394

773 from PISCO, the Partnership for Interdisciplinary Studies of Coastal Oceans funded primarily by

774 the Gordon and Betty More Foundation and David and Lucile Packard Foundation. This study

775 was made possible in part due to the data made available by the governmental agencies,

776 commercial firms, and educational institutions participating in MesoWest. Information

777 downloaded from the web site: http://www.atmos.umd.edu/ srb/gcip/webgcip.htm was

778 generated under a joint effort between the National Oceanic and Atmospheric Administration

779 (NOAA)/National Environmental Satellite Data and Information Service (NESDIS) and the

780 University of Maryland. All animals were handled in accordance with university and government

781 regulations. 
784 Behrens Yamada, S. 1989. Are direct developers more locally adapted than planktonic developers? Mar. Biol. 103: 403-411.

Behrens Yamada, S. 1992. Niche relationships in northeastern Pacific littorines. Pp. 281-291 in Proceedings of the Third International Symposium on Littorinid Biology, J. Grahame, P. J. Mill and D. G. Reid, eds. The Malacological Society of London.

Bock, C. E., and R. E. Johnson. 1967. The role of behavior in determining the intertidal zonation of Littorina planaxis Phillipi, 1847, and Littorina scutulata Gould, 1849. Veliger 10: 42-54.

Boulding, E. G., and K. L. Van Alstyne. 1993. Mechanisms of differential survival and growth of two species of Littorina on wave-exposed and on protected shores. J. Exp. Mar. Biol. Ecol. 169: 139-166.

Branch, G. M., C. L. Griffiths, M. L. Branch, and L. E. Beckley. 2002. Two Oceans: A Guide to the Marine Life of Southern Africa. David Philips Publishers, Cape Town.

Britton, J. C. 1995. The relationship between position on shore and shell ornamentation in two size-dependent morphotypes of Littorina striata, with an estimate of evaporative water loss in these morphotypes and in Melarhaphe neritoides. Hydrobiologia 309: 129-142.

Britton, J. C., and R. F. McMahon. 1986. The relationship between vertical distribution evaporative water loss rate behavior and some morphometric parameters in four species of rocky intertidal gastropods from Hong Kong. Pp. 1153-1171 in Proceedings of the Second International Marine Biological Workshop: The Marine Flora and Fauna of Hong Kong and Southern China, Hong Kong, 1986, B. Morton, ed. Hong Kong University Press, Hong Kong. 
Broekhuysen, G. J. 1940. A preliminary investigation of the importance of desiccation, temperature and salinity as factors controlling the vertical distribution of certain intertidal marine gastropods in False Bay, South Africa. Trans. R. Soc. S. Afr. 28: 255-291.

Campbell, G. S., and J. M. Norman. 1998. An Introduction to Environmental Biophysics. Springer-Verlag, New York.

Castenholz, R. W. 1961. Effect of grazing on marine littoral diatom populations. Ecology 42: 783-794.

Chapman, M. G. 1995. Spatial patterns of shell shape of three species of co-existing Littorinid snails in New South Wales, Australia. J. Molluscan Stud. 61: 141-162.

Chow, V. 1989. Intraspecific competition in a fluctuating population of Littorina plena Gould (Gastropoda: Prosobranchia). J. Exp. Mar. Biol. Ecol. 130: 147-165.

Cleland, J. D., and R. F. McMahon. 1986. Upper thermal limit of nine intertidal gastropod species from a Hong Kong rocky shore in relation to vertical distribution and desiccation associated with evaporative cooling. Pp. 1141-1152 in Proceedings of the Second International Marine Biological Workshop: The Marine Flora and Fauna of Hong Kong and Southern China, Hong Kong, 1986 B. Morton, ed. Hong Kong University Press, Hong Kong.

Clusella-Trullas, S., J. H. van Wyk, and J. R. Spotila. 2007. Thermal melanism in ectotherms. J. Therm. Biol. 32: 235-245.

Connell, J. H. 1961. Effects of competition, predation by Thais lapillus, and other factors on natural populations of the barnacle Balanus balanoides. Ecol. Monogr. 31: 61-104.

Connell, J. H. 1972. Community interactions on marine rocky intertidal shores. Annu. Rev. Ecol. Syst. 3: 169-192. 
Cook, L. M., and P. M. Freeman. 1986. Heating properties of morphs of the mangrove snail Littoraria pallescens. Biol. J. Linn. Soc. 29: 295-300.

Dayton, P. K. 1975. Experimental evaluation of ecological dominance in a rocky intertidal algal community. Ecol. Monogr. 45: 137-159.

Denny, M. W. 1984. Mechanical properties of pedal mucus and their consequences for gastropod structure and performance. Am. Zool. 24: 23-36.

Denny, M. W. 2006. Ocean waves, nearshore ecology, and natural selection. Aquat. Ecol. 40: 439-461.

Denny, M. W., and C. A. Blanchette. 2000. Hydrodynamics, shell shape, behavior and survivorship in the owl limpet Lottia gigantea. J. Exp. Biol. 203: 2623-2639.

Denny, M. W., T. L. Daniel, and M. A. R. Koehl. 1985. Mechanical limits to size in waveswept organisms. Ecol. Monogr. 55: 69-102.

Denny, M. W., and C. D. G. Harley. 2006. Hot limpets: predicting body temperature in a conductance-mediated thermal system. J. Exp. Biol. 209: 2409-2419.

Denny, M. W., B. Helmuth, G. Leonard, C. D. G. Harley, L. J. H. Hunt, and E. K. Nelson. 2004. Quantifying scale in ecology: lessons from a wave-swept shore. Ecol. Monogr. 74: 513-532.

Denny, M. W., L. J. H. Hunt, L. P. Miller, and C. D. G. Harley. 2009. On the prediction of extreme ecological events. Ecol. Monogr. 79: 397-421.

Etter, R. J. 1988. Physiological stress and color polymorphism in the intertidal snail Nucella lapillus. Evolution 42: 660-680.

Evans, F. 1961. Responses to disturbance of the periwinkle Littorina punctata (Gmelin) on a shore in Ghana. Proceedings of the Zoological Society of London 137: 393-402. 
Garrity, S. D. 1984. Some adaptations of gastropods to physical stress on a tropical rocky shore. Ecology 65: 559-574.

854 Gates, D. M. 1980. Biophysical Ecology. Springer-Verlag, New York, USA.

855 Harger, J. R. E. 1972. Competitive coexistence among intertidal invertebrates. Am. Sci. 60: $600-607$.

Harley, C. D. G. 2008. Tidal dynamics, topographic orientation, and temperature-mediated mass mortalities on rocky shores. Mar. Ecol. Prog. Ser. 371: 37-46.

Harley, C. D. G., M. W. Denny, K. J. Mach, and L. P. Miller. 2009. Thermal stress and morphological adaptations in limpets. Funct. Ecol. 23: 292-301.

Hawkins, S. J., and R. G. Hartnoll. 1983. Grazing of intertidal algae by marine invertebrates.

\section{3}

864

865

866

867 Oceanography and Marine Biology: an Annual Review 21: 195-282.

Heath, D. J. 1975. Colour, sunlight, and internal temperatures in the land-snail Cepaea nemoralis (L.). Oecologia 19: 29-38.

Heller, J. 1981. Visual versus climatic selection of shell banding in the landsnail Theba pisana in Israel. Journal of Zoology 194: 85-101.

\section{Helmuth, B., B. R. Broitman, C. A. Blanchette, S. E. Gilman, P. M. Halpin, C. D. G.} Harley, M. J. O'Donnell, G. E. Hofmann, B. A. Menge, and D. Strickland. 2006. Mosaic patterns of thermal stress in the rocky intertidal zone: implications for climate change. Ecol. Monogr. 76: 461-479.

\section{Helmuth, B., C. D. G. Harley, P. M. Halpin, M. O'Donnell, G. E. Hofmann, and C. A.} Blanchette. 2002. Climate change and latitudinal patterns of intertidal thermal stress. Science 298: 1015-1017. 
Hidalgo, F. J., F. N. Firstater, E. Fanjul, M. C. Bazterrica, B. J. Lomovasky, J. Tarazona, and O. O. Iribarne. 2008. Grazing effects of the periwinkle Echinolittorina peruviana at a central Peruvian high rocky intertidal. Helgol. Mar. Res. 62: S73-S83.

Huey, R. B. 1991. Physiological consequences of habitat selection. The American Naturalist 137: S91-S115.

Hughes, J. M., and P. B. Mather. 1986. Evidence for predation as a factor in determining shell color frequencies in a mangrove snail Littorina sp. (Prosobranchia: Littorinidae). Evolution 40: 68-77.

Johannesson, B. 1986. Shell morphology of Littorina saxatilis Olivi: the relative importance of physical factors and predation. J. Exp. Mar. Biol. Ecol. 102: 183-195.

Johannesson, K. 2003. Evolution in Littorina: ecology matters. J. Sea Res. 49: 107-117.

Johannesson, K., and A. Ekendahl. 2002. Selective predation favouring cryptic individuals of marine snails (Littorina). Biol. J. Linn. Soc. 76: 137-144.

Johannesson, K., B. Johannesson, and E. Rolán-Alvarez. 1993. Morphological differentiation and genetic cohesiveness over a microenvironmental gradient in the marine snail Littorina saxatilis. Evolution 47: 1770-1787.

Johnsen, S., and E. A. Widder. 1999. The physical basis of transparency in biological tissue: ultrastructure and the minimization of light scattering. J. Theor. Biol. 199: 181-198.

Jones, J. S. 1973. Ecological genetics and natural selection in mollusks. Science 182: 546-552.

Judge, M. L., R. Duell, L. Burriesci, and W. Moarsi. 2009. Life in the supralittoral fringe: microhabitat choice, mobility and growth in the tropical periwinkle Cenchritis (=Tectarius) muricatus (Linneaus, 1758). J. Exp. Mar. Biol. Ecol. 369: 148-154. 
Kearney, M., R. Shine, and W. P. Porter. 2009. The potential for behavioral thermoregulation to buffer "cold-blooded" animals against climate warming. Proc. Natl. Acad. Sci. U.S.A. 106: $3835-3840$.

Kingsolver, J. G. 1996. Experimental manipulation of wing pigment pattern and survival in western white butterflies. The American Naturalist 147: 296-306.

Kronberg, I. 1990. Heat production in Littorina saxatilis Olivi and Littorina neritoides L. (Gastropoda: Prosobranchia) during an experimental exposure to air. Helgol. Wiss. Meeresunters. 44: 125-134.

Lang, R. C., J. C. Britton, and T. Metz. 1998. What to do when there is nothing to do: The ecology of Jamaican intertidal Littorinidae (Gastropoda: Prosobranchia) in repose. Hydrobiologia 378: 161-185.

Lewis, J. R. 1964. Ecology of Rocky Shores. English Universities Press, London.

Machin, J. 1967. Structural adaptation for reducing water-loss in three species of terrestrial snail. Journal of Zoology 152: 55-65.

Manríquez, P. H., N. A. Lagos, M. E. Jara, and J. C. Castilla. 2009. Adaptive shell color plasticity during the early ontogeny of an intertidal keystone snail. Proc. Natl. Acad. Sci. U.S.A. 106: $16298-16303$.

Markel, R. P. 1971. Temperature relations in two species of tropical west American littorines. Ecology 52: 1126-1130.

Marshall, D. J., C. D. McQuaid, and G. A. Williams. 2010. Non-climatic thermal adaptation: implications for species' responses to climate warming. Biology Letters 6: 669-673.

McMahon, R. F. 1990. Thermal tolerance evaporative water loss air-water oxygen consumption and zonation of intertidal prosobranchs: a new synthesis. Hydrobiologia 193: 241-260. 
McMahon, R. F., and J. C. Britton. 1985. The relationship between vertical distribution,

920

921

922

923

924

925

926

927

928

929

930

931

932

933

934

935

936

937

938

939

940

thermal tolerance, evaporative water loss rate, and behavior on emergence in six species of mangrove gastropods from Hong Kong. Pp. 563-582 in The Malacofauna of Hong Kong and Southern China. II, Vol. 1 and 2. Second International Workshop: Hong Kong, Hong Kong, Apr. 6-24, 1983., B. Morton and D. Dudgeon, eds. Hong Kong University Press, Hong Kong.

McMahon, R. F., and W. D. Russell-Hunter. 1977. Temperature relations of aerial and aquatic respiration in six littoral snails in relation to their vertical zonation. Biol. Bull. 152: 182198.

McQuaid, C. D. 1992. Stress on the high shore: a review of age-dependent causes of mortality in Nodilittorina knysnaensis and N. africana. Pp. 85-89 in Proceedings of the Third International Symposium on Littorinid Biology, J. Grahame, P. J. Mill and D. G. Reid, eds. The Malacological Society of London, London.

McQuaid, C. D. 1996a. Biology of the gastropod family Littorinidae. I. Evolutionary aspects. Oceanography and Marine Biology: an Annual Review 34: 233-262.

McQuaid, C. D. 1996b. Biology of the gastropod family Littorinidae. II. Role in the ecology of intertidal and shallow marine ecosystems. Oceanography and Marine Biology: an Annual Review 34: 263-302.

McQuaid, C. D., and P. A. Scherman. 1988. Thermal stress in a high shore intertidal environment: morphological and behavioural adaptations of the gastropod Littorina africana. Pp. 213-224 in Behavioral Adaptation to Intertidal Life, G. Chelazzi and M. Vannini, eds. Plenum Press, New York. 
941 Menge, B. A., and G. M. Branch. 2001. Rocky Intertidal Communities. Pp. 221-251 in Marine 942 Community Ecology, M. D. Bertness, S. D. Gaines and M. E. Hay, eds. Sinauer 943 Associates, Inc., Sunderland, Massachusetts.

944 Miller, L. P. 2008. Life on the edge: morphological and behavioral adaptations for survival on 945 wave-swept shores, $\mathrm{PhD}$ Thesis, Biology, Stanford University.

946 Miller, L. P., C. D. G. Harley, and M. W. Denny. 2009. The role of temperature and 947 desiccation stress in limiting the local-scale distribution of the owl limpet, Lottia $948 \quad$ gigantea. Funct. Ecol. 23: 756-767.

949 Miller, L. P., M. J. O'Donnell, and K. J. Mach. 2007. Dislodged but not dead: survivorship of 950 a high intertidal snail following wave dislodgement. J. Mar. Biol. Assoc. U. K. 87: 735$951 \quad 739$.

952 Miller, S. L. 1974. Adaptive design of locomotion and foot form in prosobranch gastropods. $J$. 953 Exp. Mar. Biol. Ecol. 14: 99-156.

954 Mislan, K. A. S., D. S. Wethey, and B. Helmuth. 2009. When to worry about the weather: role 955 of tidal cycle in determining patterns of risk in intertidal ecosystems. Global Change Biology 15: 3056-3065.

Muñoz, J. L. P., G. R. Finke, P. A. Camus, and F. Bozinovic. 2005. Thermoregulatory behavior, heat gain, and thermal tolerance in the periwinkle Echinolittorina peruviana in central Chile. Comparative Biochemistry and Physiology, Part A 142: 92-98.

960 Newell, G. E. 1958. The behaviour of Littorina littorea (L.) under natural conditions and its 961 relation to position on the shore. J. Mar. Biol. Assoc. U. K. 37: 229-239.

962 Newell, R. C. 1976. Adaptations to intertidal life. Pp. 1-82 in Adaptation to Environment: Essays 963 on the Physiology of Marine Animals, R. C. Newell, ed. Butterworths, London, UK. 
Norton, T. A., S. J. Hawkins, N. L. Manley, G. A. Williams, and D. C. Watson. 1990. Scraping a living: a review of littorinid grazing. Hydrobiologia 193: 117-138.

O'Connor, M. P., and J. R. Spotila. 1992. Consider a spherical lizard: animals, models, and approximations. Am. Zool. 32: 179-193.

Ohgaki, S.-i. 1988. Rain and the distribution of Nodilittorina exigua (Dunker) (Gastropoda: Littorinidae). J. Exp. Mar. Biol. Ecol. 122: 213-223.

Paine, R. T. 1974. Intertidal community structure - experimental studies on relationship between a dominant competitor and its principal predator. Oecologia 15: 93-120.

Pardo, L. M., and L. E. Johnson. 2005. Explaining variation in life-history traits: growth rate, size, and fecundity in a marine snail across an environmental gradient lacking predators. Mar. Ecol. Prog. Ser. 296: 229-239.

Phifer-Rixey, M., M. Heckman, G. C. Trussell, and P. S. Schmidt. 2008. Maintenance of clinal variation for shell colour phenotype in the flat periwinkle Littorina obtusata. J. Evol. Biol. 21: 966-978.

Porter, W. P., and D. M. Gates. 1969. Thermodynamic equilibria of animals with environment. Ecol. Monogr. 39: 228-244.

Porter, W. P., and M. Kearney. 2009. Size, shape, and the thermal niche of endotherms. Proc. Natl. Acad. Sci. U.S.A. 106: 19666-19672.

Porter, W. P., J. W. Mitchell, W. A. Beckman, and C. B. DeWitt. 1973. Behavioral implications of mechanistic ecology: thermal and behavioral modeling of desert ecototherms and their microenvironment. Oecologia 13: 1-54.

R Development Core Team 2010. R: A language and environment for statistical computing. $\mathrm{R}$ Foundation for Statistical Computing, Vienna, Austria. http://www.R-project.org/ 
Rasband, W. S. 1997-2010. ImageJ. U. S. National Institutes of Health, Bethesda, Maryland, USA. http://rsb.info.nih.gov/ij/

Reid, D. G. 1987. Natural selection for apostasy and crypsis acting on the shell color polymorphism of a mangrove snail, Littoraria filosa (Sowerby) (Gastropoda: Littorinidae). Biol. J. Linn. Soc. 30: 1-24.

Reid, D. G. 1996. Systematics and Evolution of Littorina. The Dorset Press, Dorchester, UK.

Reid, D. G. 2002. Morphological review and phylogenetic analysis of Nodilittorina (Gastropoda: Littorinidae). J. Molluscan Stud. 68: 259-281.

Reimchen, T. E. 1979. Substratum heterogeneity, crypsis, and colour polymorphism in an intertidal snail (Littorina mariae). Canadian Journal of Zoology 57: 1070-1085.

Rochette, R., and L. M. Dill. 2000. Mortality, behavior and the effects of predators on the intertidal distribution of littorinid gastropods. J. Exp. Mar. Biol. Ecol. 253: 165-191.

Schmidt-Nielsen, K., C. R. Taylor, and A. Shkolnik. 1971. Desert snails: problems of heat, water and food. J. Exp. Biol. 55: 385-398.

Schmidt-Nielsen, K., C. R. Taylor, and A. Shkolnik. 1972. Desert snails: Problems of survival. Pp. 1-13 in Comparative Physiology of Desert Animals, G. M. O. Maloiy, ed. Academic Press, London.

Seeley, R. H. 1986. Intense natural selection caused a rapid morphological transition in a living marine snail. Proc. Natl. Acad. Sci. U.S.A. 83: 6897-6901.

Sergievsky, S. O. 1992. A review of ecophysiological studies of the colour polymorphism of Littorina obtusata (L.) and L. saxatilis (Olivi) in the White Sea. Pp. 235-245 in Proceedings of the Third International Symposium on Littorinid biology, J. Grahame, P. J. Mill and D. G. Reid, eds. The Malacological Society of London, London. 
1010 Sokolova, I. M., and H.-O. Pörtner. 2003. Metabolic plasticity and critical temperatures for 1011 aerobic scope in a eurythermal marine invertebrate (Littorina saxatilis, Gastropoda:

1012 Littorinidae) from different latitudes. J. Exp. Biol. 206: 195-207.

1013 Somero, G. N. 2002. Thermal physiology and vertical zonation of intertidal animals: Optima, 1014 limits, and costs of living. Integr. Comp. Biol. 42: 780-789.

1015 Stearns, R. E. C. 1877. On the vitality of certain land mollusks. Am. Nat. 11: 100-102.

1016 Stephenson, T. A., and A. Stephenson. 1972. Life between tidemarks on rocky shores. W. H. 1017 Freeman and Company, San Francisco.

1018 Stevenson, R. D. 1985. The relative importance of behavioral and physiological adjustments 1019 1020 controlling body temperature in terrestrial ectotherms. The American Naturalist 126: 362-386.

Stirling, H. P. 1982. The upper temperature tolerance of prosobranch gastropods of rocky shores at Hong Kong and Dar ES Salaam, Tanzania. J. Exp. Mar. Biol. Ecol. 63: 133-144.

Struhsaker, J. W. 1968. Selection mechanisms associated with intraspecific shell variation in Littorina picta (Prosobranchia: Mesogastropoda). Evolution 22: 459-480.

1025 Tomanek, L. 2010. Variation in the heat shock response and its implication for predicting the 1026 effect of global climate change on species' biogeographical distribution ranges and metabolic costs. J. Exp. Biol. 213: 971-979.

1028 Trussell, G. C. 1997a. Phenotypic plasticity in the foot size of an intertidal snail. Ecology 78: $1029 \quad$ 1033-1048.

1030 Trussell, G. C. 1997b. Phenotypic selection in an intertidal snail: Effects of a catastrophic 1031 storm. Mar. Ecol. Prog. Ser. 151: 73-79. 
1032 Trussell, G. C. 2000. Predator-induced plasticity and morphological trade-offs in latitudinally separated populations of Littorina obtusata. Evol. Ecol. Res. 2: 803-822.

1034 Trussell, G. C. 2002. Evidence of countergradient variation in the growth of an intertidal snail in 1035 response to water velocity. Mar. Ecol. Prog. Ser. 243: 123-131.

Trussell, G. C., and M. O. Nicklin. 2002. Cue sensitivity, inducible defense, and trade-offs in a marine snail. Ecology 83: 1635-1647.

Vermeij, G. J. 1971a. Substratum relationships of some tropical Pacific intertidal gastropods. Mar. Biol. 10: 345-320.

Vermeij, G. J. 1971b. Temperature relationships of some tropical Pacific intertidal gastropods. Mar. Biol. 10: 308-314.

Vermeij, G. J. 1972. Intraspecific shore level size gradients in intertidal mollusks. Ecology 53: 693-700.

Vermeij, G. J. 1973. Morphological patterns in high-intertidal gastropods: adaptive strategies and their limitations. Mar. Biol. 20: 319-346.

1046 Wada, S., and A. Ito. 2000. Preliminary observation on "tip-lip" attachment in the periwinkle Nodilittorina radiata. Bull. Mar. Sci. Fish. Kochi Univ. 20: 15-24.

1048 Wethey, D. S. 2002. Biogeography, competition, and microclimate: The barnacle Chthamalus 1049 fragilis in New England. Integr. Comp. Biol. 42: 872-880.

1050 Williams, S. T., D. G. Reid, and D. T. J. Littlewood. 2003. A molecular phylogeny of the 1051 Littorininae (Gastropoda: Littorinidae): unequal evolutionary rates, morphological 1052 parallelism, and biogeography of the Southern Ocean. Molecular Phylogenetics and $1053 \quad$ Evolution 28: 60-86. 
1054 Wilson, D. P. 1929. A habit of the common periwinkle (Littorina littorea Linn). Nature 124: 1055443.

1056

1057 
1058 Table 1. Measured shell parameters for the five littorinid species used in this study.

\begin{tabular}{|c|c|c|c|c|c|c|}
\hline Parameter & Units & $\begin{array}{c}\text { Littorina } \\
\text { keenae }\end{array}$ & $\begin{array}{l}\text { Littorina } \\
\text { scutulata }\end{array}$ & $\begin{array}{c}\text { Littorina } \\
\text { plena }\end{array}$ & $\begin{array}{l}\text { Littorina } \\
\text { sitkana }\end{array}$ & $\begin{array}{c}\text { Echinolittorina } \\
\text { natalensis }\end{array}$ \\
\hline Shell length & $\mathrm{mm}$ & 10.8 & 6.1 & 5.7 & 6.6 & 6.3 \\
\hline \multicolumn{7}{|l|}{ Area for conductive flux, } \\
\hline foot extended & $\mathrm{mm}^{2}$ & 58.5 & 10.3 & 10.9 & 15.5 & 11.4 \\
\hline \multicolumn{7}{|l|}{ Area for conductive flux, } \\
\hline foot withdrawn & $\mathrm{mm}^{2}$ & 2.20 & 1.02 & 0.84 & 1.02 & 0.71 \\
\hline \multicolumn{7}{|l|}{ Area for conductive flux, } \\
\hline shell up & $\mathrm{mm}^{2}$ & 0.34 & 0.14 & 0.10 & 0.29 & 0.25 \\
\hline \multicolumn{7}{|l|}{ Area for convective flux, } \\
\hline shell down & $\mathrm{mm}^{2}$ & 287.4 & 69.9 & 65.4 & 106.9 & 67.2 \\
\hline \multicolumn{7}{|l|}{ Area for convective } \\
\hline flux, shell up & $\mathrm{mm}^{2}$ & 347.8 & 81.1 & 77.0 & 123.1 & 85.6 \\
\hline Maximum projected area & $\mathrm{mm}^{2}$ & 104.8 & 24.6 & 22.9 & 37.1 & 25.5 \\
\hline Minimum projected area & $\mathrm{mm}^{2}$ & 65.8 & 14.3 & 13.0 & 22.4 & 16.5 \\
\hline \multicolumn{7}{|l|}{ Conduction distance } \\
\hline (shell down) & $\mathrm{mm}$ & 0.42 & 0.31 & 0.32 & 0.63 & 0.55 \\
\hline \multicolumn{7}{|l|}{ Conduction distance } \\
\hline (shell up) & $\mathrm{mm}$ & 2.57 & 1.41 & 1.25 & 1.44 & 1.32 \\
\hline
\end{tabular}


1060 Table 2. Sites on the west coast of North America used to model maximum body temperature for

1061 L. scutulata from August 2007 to August 2009. The relevant NOAA tide monitoring station ID

1062 from which data were obtained is given for each site, except La Jolla, CA, where data were

1063 obtained from the Scripps Institute of Oceanography archive. Maximum water level is the

1064 highest measured tide height during the survey period, referenced to mean lower low water.

\begin{tabular}{lllll}
\hline Tide Station & NOAA & Latitude $\left({ }^{\circ} \mathrm{N}\right)$ & Longitude $\left({ }^{\circ} \mathrm{W}\right)$ & Maximum \\
& Station ID & & & water level $(\mathrm{m})$ \\
\hline Friday Harbor, WA & 9449880 & 48.522 & 123.025 & 2.93 \\
Neah Bay, WA & 9443090 & 48.367 & 124.612 & 3.29 \\
Toke Point, WA & 9440910 & 46.707 & 124.042 & 3.65 \\
Newport, OR & 9435380 & 44.625 & 124.042 & 3.25 \\
Charleston, OR & 9432780 & 43.345 & 124.322 & 2.95 \\
Crescent City, CA & 9419750 & 41.745 & 124.182 & 2.67 \\
Point Arena, CA & 9416841 & 38.913 & 123.706 & 2.43 \\
San Francisco, CA & 9414290 & 37.806 & 122.465 & 2.26 \\
Pacific Grove, CA & 9413450 & 36.622 & 121.904 & 2.21 \\
Los Angeles, CA & 9410660 & 33.720 & 118.272 & 2.30 \\
La Jolla, CA & $*$ SIO & 32.867 & 117.257 & 2.26 \\
\hline
\end{tabular}


1066 Table 3. Comparison of measured temperatures of epoxy-filled shells and live snails in the field 1067 with predicted model temperatures using weather data from the same time period.

\begin{tabular}{|c|c|c|}
\hline \multirow[t]{4}{*}{ Species } & Mean difference & Mean difference between \\
\hline & between all modeled and & modeled and measured \\
\hline & measured temperatures & temperatures for top $1 \%$ \\
\hline & $\left({ }^{\circ} \mathrm{C} \pm \mathrm{SD}\right)$ & of temperatures $\left({ }^{\circ} \mathrm{C} \pm \mathrm{SD}\right)$ \\
\hline
\end{tabular}

\section{Shell mimic, shell down}

\begin{tabular}{lll}
\hline Littorina keenae & $-1.13( \pm 1.51)$ & $0.64( \pm 0.63)$ \\
Littorina scutulata & $0.20( \pm 1.31)$ & $0.05( \pm 0.46)$ \\
Littorina sitkana & $-0.75( \pm 0.95)$ & $-0.09( \pm 0.19)$ \\
Littorina plena & $0.17( \pm 0.88)$ & $-0.07( \pm 0.24)$ \\
Echinolittorina natalensis & $-0.21( \pm 1.07)$ & $0.00( \pm 0.41)$
\end{tabular}

Shell mimic, shell up

\begin{tabular}{llc}
\hline Littorina keenae & $-1.47( \pm 2.40)$ & $0.45( \pm 0.78)$ \\
Littorina scutulata & $-1.03( \pm 1.14)$ & $0.11( \pm 0.63)$ \\
Littorina sitkana & $-0.10( \pm 0.79)$ & $-0.21( \pm 0.28)$ \\
Littorina plena & $-0.73( \pm 1.28)$ & $0.16( \pm 0.81)$ \\
Echinolittorina natalensis & $-0.55( \pm 0.89)$ & $-0.17( \pm 0.62)$ \\
\hline Live snails, shell down & & \\
\hline L. keenae 1 & $-0.56( \pm 1.50)$ & $-0.06( \pm 0.86)$ \\
L. keenae 2 & $-1.00( \pm 1.50)$ & $0.17( \pm 0.29)$ \\
\hline
\end{tabular}

1068 
1070 Table 4. Summary of temperatures of three pairs of similarly-sized live black-shelled and white-

1071 shelled Littorina keenae deployed on a high intertidal rock during a heat wave on May $14-16$,

1072 2008. Temperature differences between each black and white pair are calculated for times from

1073 one hour after sunrise to one hour before sunset, and during the four hottest hours of the day.

\begin{tabular}{|c|c|c|c|c|c|c|}
\hline \multicolumn{7}{|l|}{ Temperature difference $\left({ }^{\circ} \mathrm{C}\right)$} \\
\hline \multicolumn{7}{|l|}{ black - white shell } \\
\hline $6: 00-18: 00$ & \multicolumn{2}{|c|}{ Pair 1} & \multicolumn{2}{|c|}{ Pair 2} & \multicolumn{2}{|c|}{ Pair 3} \\
\hline Average $\pm 1 \mathrm{SD}, \mathrm{n}=2160$ & \multicolumn{2}{|c|}{$0.11 \pm 0.69$} & \multicolumn{2}{|c|}{$0.43 \pm 0.41$} & \multicolumn{2}{|c|}{$0.10 \pm 0.71$} \\
\hline Maximum & \multicolumn{2}{|c|}{2.29} & \multicolumn{2}{|c|}{2.39} & \multicolumn{2}{|c|}{2.15} \\
\hline Minimum & \multicolumn{2}{|c|}{-1.40} & \multicolumn{2}{|c|}{-0.78} & \multicolumn{2}{|c|}{-2.17} \\
\hline \multicolumn{7}{|l|}{ Temperature difference $\left({ }^{\circ} \mathrm{C}\right)$} \\
\hline \multicolumn{7}{|l|}{ black - white shell } \\
\hline \multicolumn{7}{|l|}{$11: 00-15: 00$} \\
\hline Average $\pm 1 \mathrm{SD}, \mathrm{n}=720$ & \multicolumn{2}{|c|}{$-0.08 \pm 0.54$} & \multicolumn{2}{|c|}{$0.48 \pm 0.33$} & \multicolumn{2}{|c|}{$0.31 \pm 0.66$} \\
\hline Maximum & \multicolumn{2}{|c|}{2.06} & \multicolumn{2}{|c|}{2.12} & \multicolumn{2}{|c|}{2.02} \\
\hline Minimum & \multicolumn{2}{|c|}{-1.08} & \multicolumn{2}{|c|}{-0.78} & \multicolumn{2}{|c|}{-1.61} \\
\hline Cumulative data, May 14-16 & Black & White & Black & White & Black & White \\
\hline Maximum temperature $\left({ }^{\circ} \mathrm{C}\right)$ & 43.8 & 42.5 & 43.4 & 42.7 & 43.7 & 42.9 \\
\hline Time above $30^{\circ} \mathrm{C}(\mathrm{hr})$ & 18.7 & 18.5 & 19.2 & 19.1 & 19.4 & 19.1 \\
\hline Time above $40^{\circ} \mathrm{C}(\mathrm{hr})$ & 1.5 & 1.25 & 2.05 & 1.47 & 2.38 & 2.0 \\
\hline
\end{tabular}

1074 
1076 Figure 1. Littorinid snails can often be found (A) with the foot withdrawn into the shell and the 1077 shell glued to the substratum, or (B) with the shell elevated up off the substratum, perched on the

1078 outer lip of the shell aperture. C) Representative shells of the five species used in the heat-budget 1079 model. From left to right: Littorina keenae, L. scutulata, L. plena, L. sitkana, Echinolittorina 1080 natalensis.

1081 Figure 2. Measured vs. predicted temperatures for silver-epoxy-filled shells set out in the field. 1082 The left column shows the relationship when the shells were positioned with the aperture down 1083 against the substratum. The right column shows data for the same shells re-oriented up onto the 1084 edge of the shell lip. Data were collected during April 23-29 and June 3-7, 2007, at HMS.

1085 Figure 3. Mean temperature differences ( \pm 1 SD) between modeled snails during the hottest $1 \%$ 1086 of all time periods in the $10 \mathrm{yr}$ weather data set $(\mathrm{n}=5620)$. Maximum differences are denoted by 1087 the + symbol above each bar. A) Comparison of snails modeled with the foot always on the rock, 1088 or withdrawn into the shell during hot periods. Snails with the foot in contact with the rock reach 1089 higher temperatures. B) Comparison of snails modeled with the foot withdrawn into the shell, 1090 and the snail either resting aperture-down on the substratum or perched on the outer lip of the 1091 shell. Leaving the shell resting on the substratum results in higher body temperatures. C)

1092 Temperature differences between a black shell and alternate shell color morphs. Each color 1093 morph was modeled with the foot withdrawn and shell perched on the outer lip of the shell.

1094 Black shells are always warmer than the alternate color morphs.

1095 Figure 4. A) Predicted daily maximum body temperatures for a black L. keenae modeled with the 1096 foot out in contact with the substratum at all times or withdrawn into the shell during low tide. B) 
1097 Predicted daily maximum body temperatures for the same L. keenae with the foot withdrawn and

1098 the shell sitting down on the substratum or with the shell tipped up on the edge of the aperture

1099 lip. Temperatures were predicted using environmental data for HMS from 1999-2009 $(\mathrm{n}=3652$

1100 days). The snail was modeled on horizontal substratum at $2.0 \mathrm{~m}$ above mean lower low water. A

1101 line of unity is plotted in both panels.

1102 Figure 5. Maximum predicted body temperatures for a black L. scutulata at eleven sites along the 1103 west coast of North America, using environmental data from 1 August 2007 through 1 August 1104 2009. Temperatures are given for the same snail in three positions: with the foot out on the rock

1105 at all times, with the foot withdrawn into the shell at low tide, and with the shell tipped up on 1106 edge during low tide. All models were run with the snail sitting on a horizontal surface at the 1107 height of the maximum still tide level for each site.

1108 Figure 6. Maximum predicted body temperatures for a black snail shell (solid line) and white 1109 snail (dashed line) modeled with a range of contact areas on the substratum, using environmental 1110 data from HMS for 1999-2009. The shaded areas represent the typical range of contact areas for 1111 littorinid snails with only the lip of the shell glued to the substratum (1 point), resting on the lip 1112 and main whorl of the shell (2 points), or attached by the foot. As contact area increases,

1113 conductive heat flux reduces the effect of shell color differences on body temperature.

1114 Figure 7. Temperature differences between black and white morphs of L. keenae, for all daytime 1115 low tide periods when air temperature was less than $15^{\circ} \mathrm{C}$. A) Temperature differences for snails 1116 modeled with the foot withdrawn and the shell elevated up onto the outer lip of the aperture.

1117 Black shells were warmer than white shells. B) Temperature differences for black vs. white 1118 snails modeled with the foot always in contact with the substratum. Comparisons were made for 
1119 each meteorological season using weather data from HMS for 1999-2009. The center line in each

1120 box represents the median temperature difference between the two color morphs at each time

1121 point, and the upper and lower bounds of each box denote the $1^{\text {st }}$ and $3^{\text {rd }}$ quartiles, respectively.

1122 Crosses above a boxplot represent outliers. Box width represents the relative sample size in each

1123 season (Spring $=29,918$ samples in both panels). Sample size varies between seasons due to the

1124 timing of low tides, wave action, and day length.

1125 Figure 8. A) Calculated heat transfer coefficients for similarly-sized E. natalensis (black line)

1126 and L. scutulata (gray line). Higher values increase the convective heat exchange with the

1127 surrounding air. Values are calculated for $25^{\circ} \mathrm{C}$ air temperature and shells sitting with the

1128 aperture against the substratum. B) Predicted body temperatures for a representative hot day, for

1129 brown snails of each species modeled with the foot withdrawn and shell resting on the

1130 substratum. The sculptured shell of E. natalensis was $0.2^{\circ} \mathrm{C}$ cooler on average compared to the

1131 smooth shell of L. scutulata under identical weather conditions. The wind speed on this day was

$11321.2 \pm 0.6 \mathrm{~m} \mathrm{~s}^{-1}($ mean $\pm 1 \mathrm{SD})$. 


\section{A)}

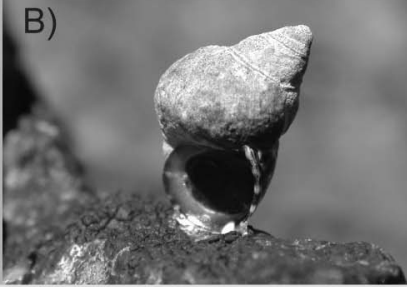

\section{C)}
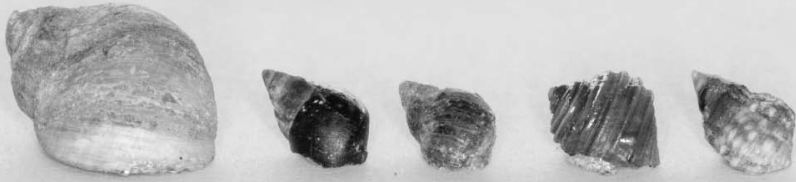

$5 \mathrm{~mm}$ 

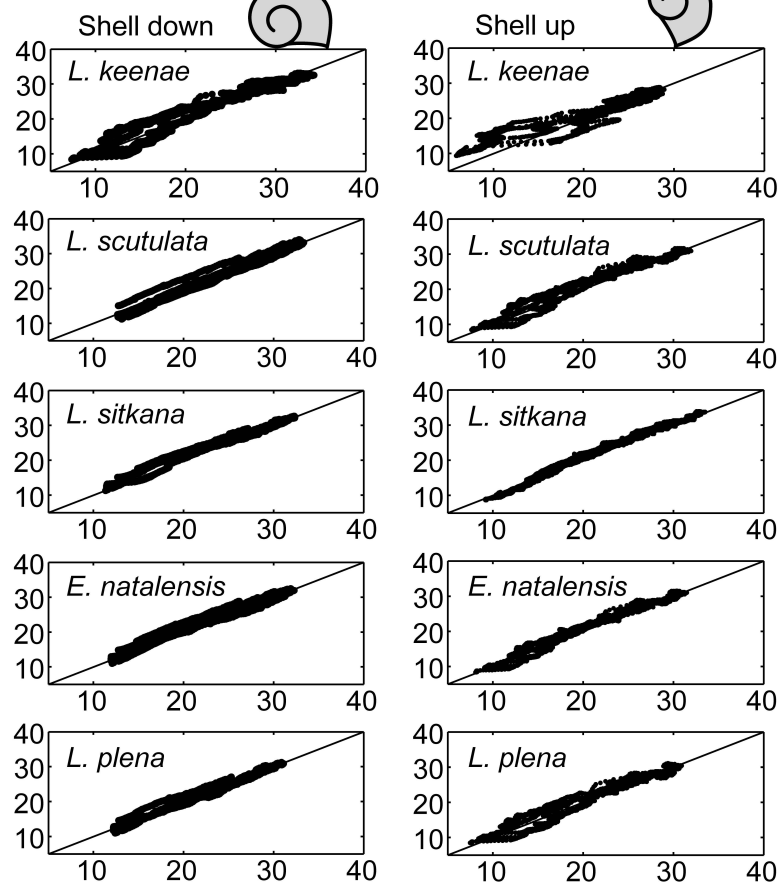

Predicted temperature $\left({ }^{\circ} \mathrm{C}\right)$ 


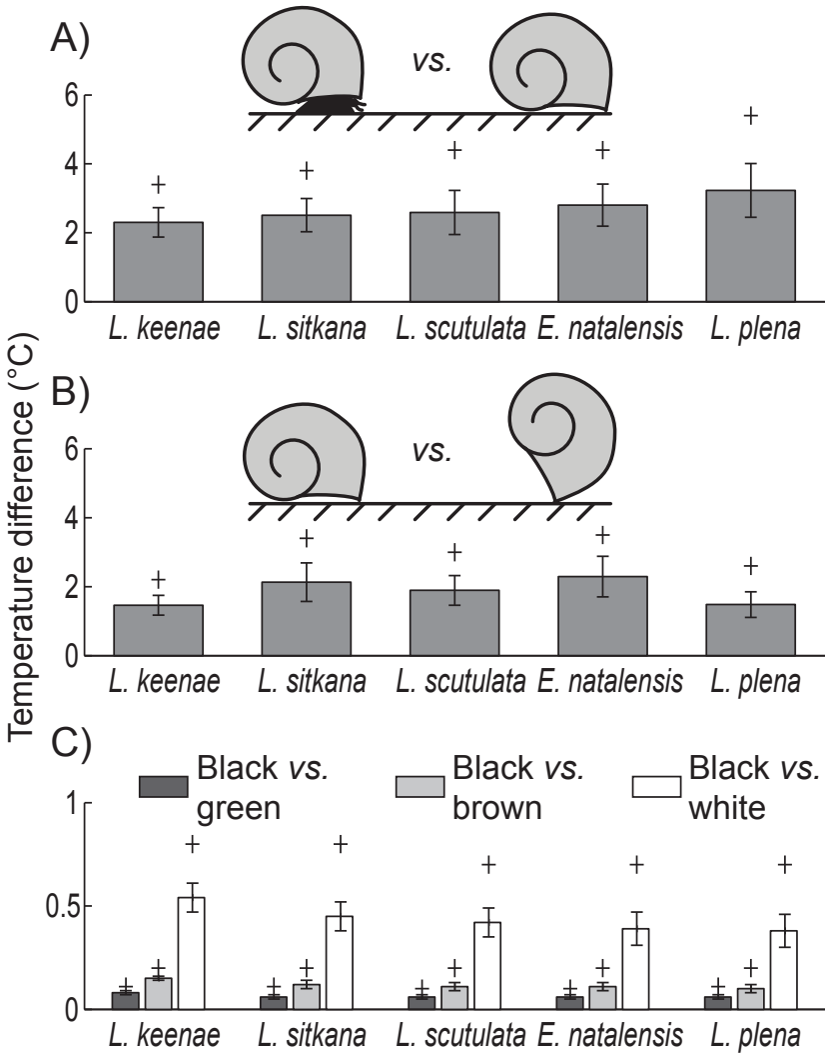


A)

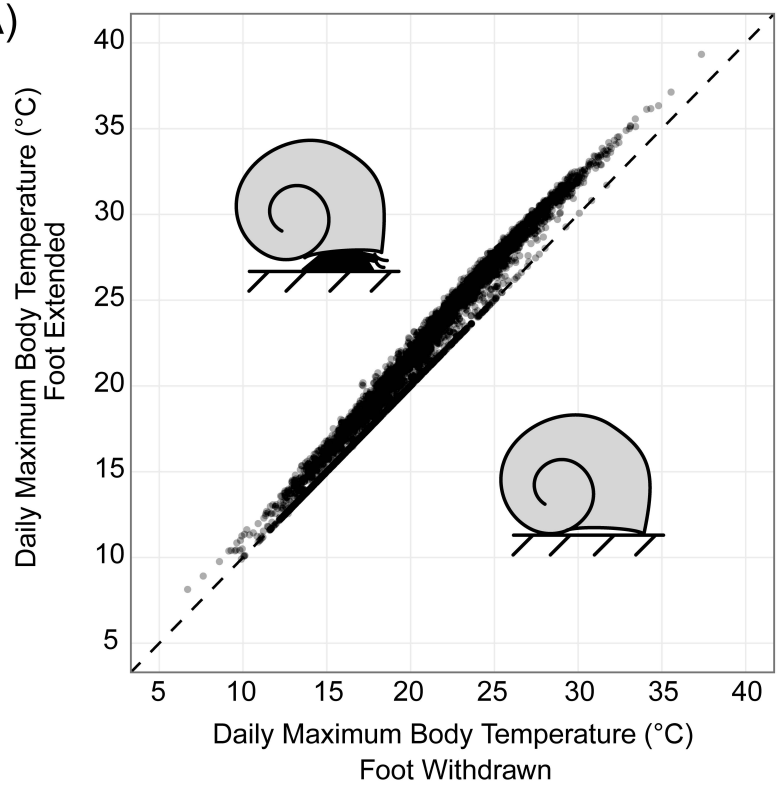

B)

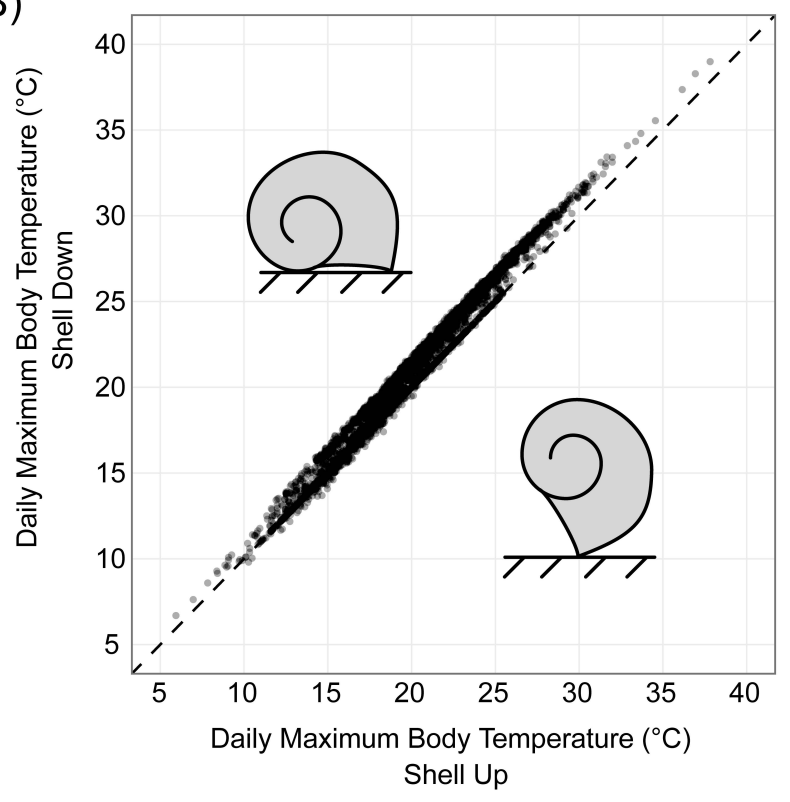




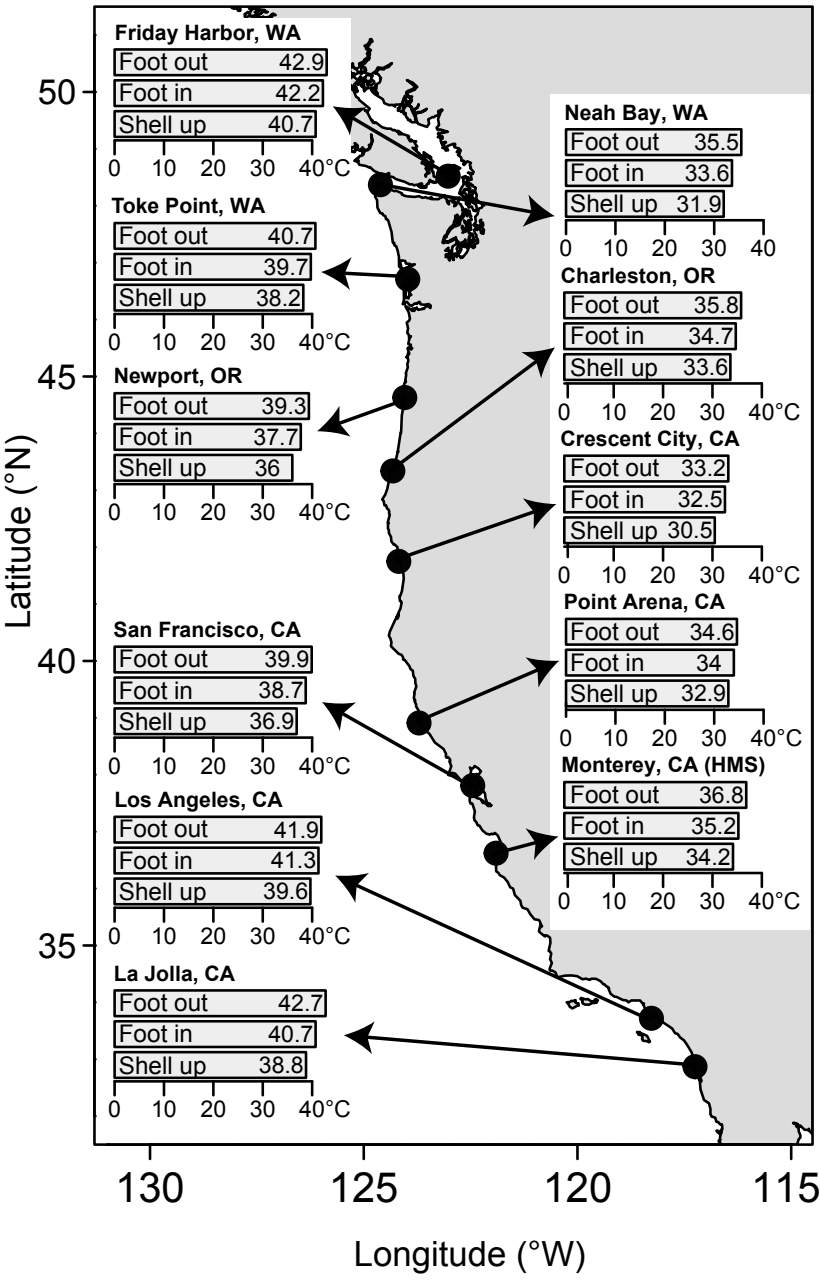




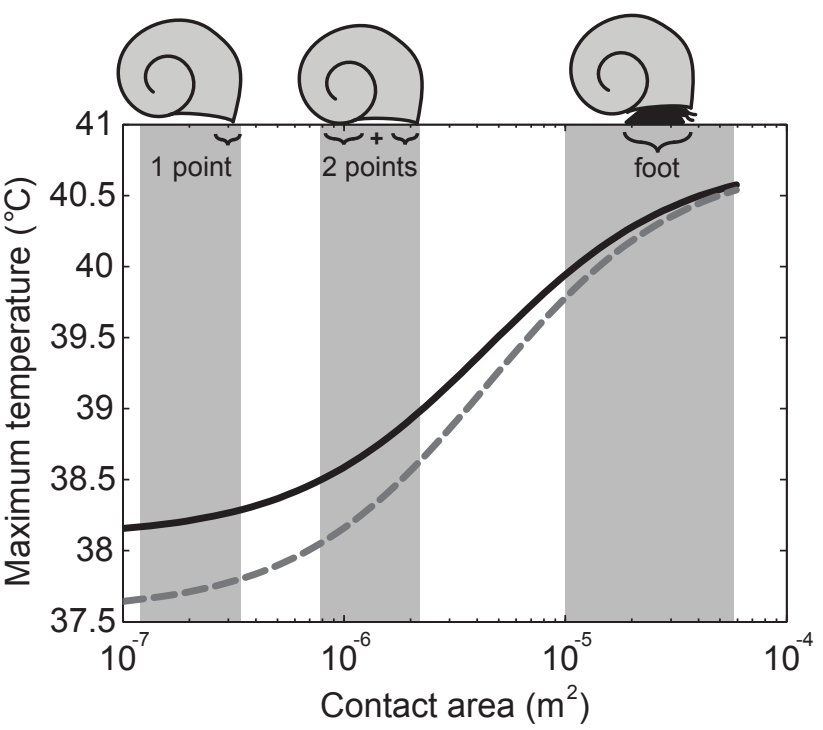


A)

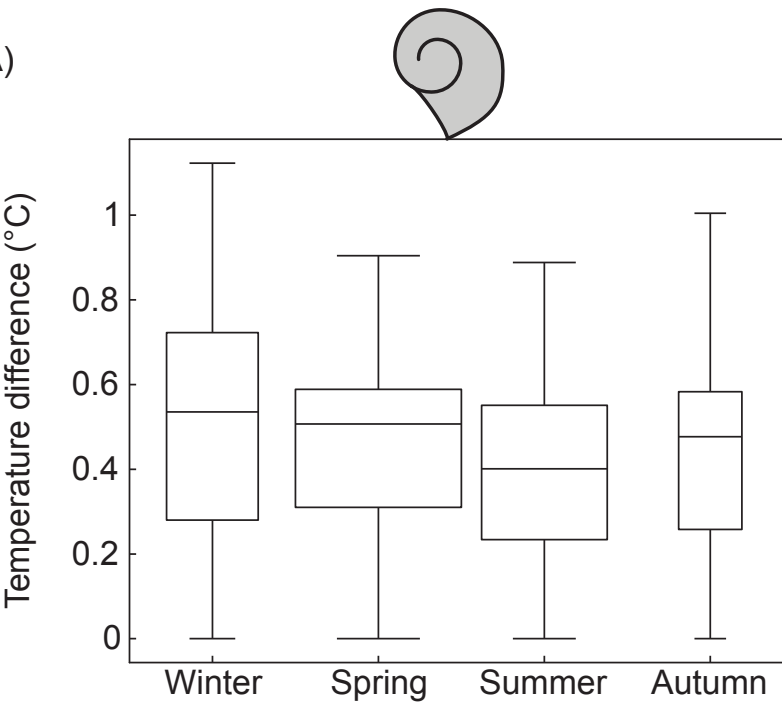

B)

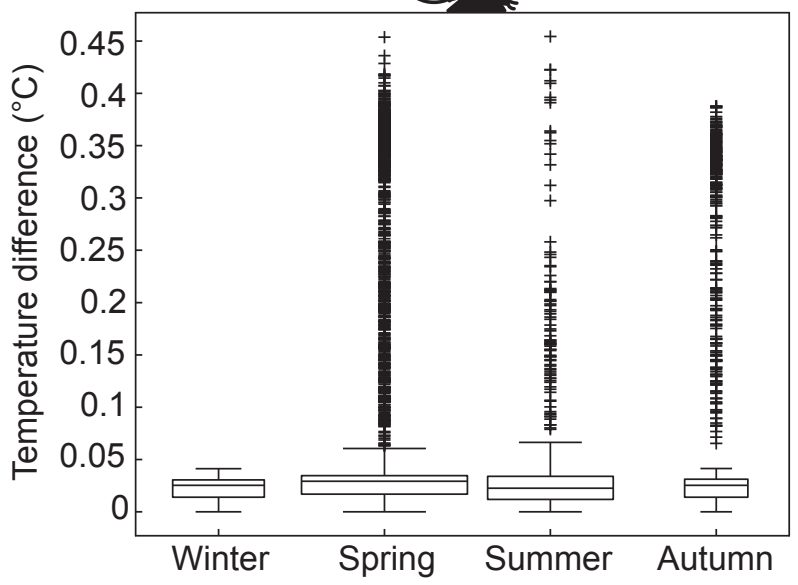


A)

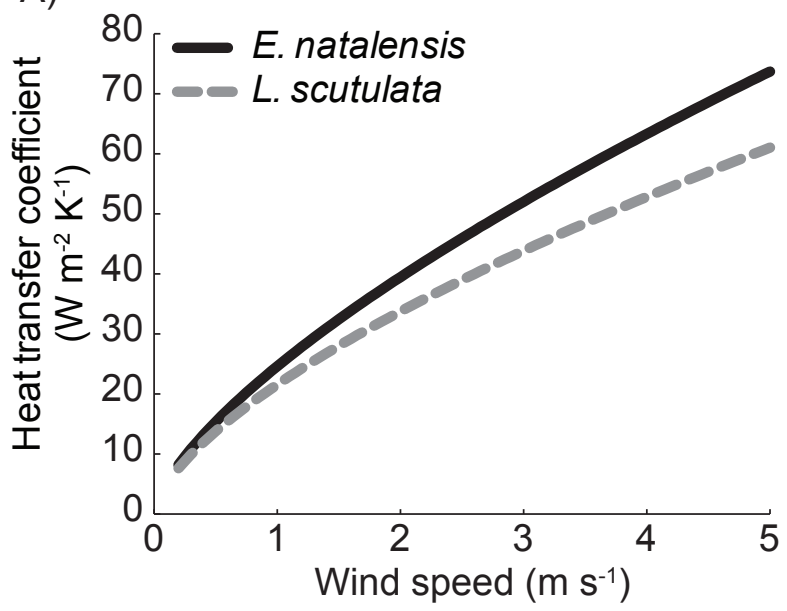

B)

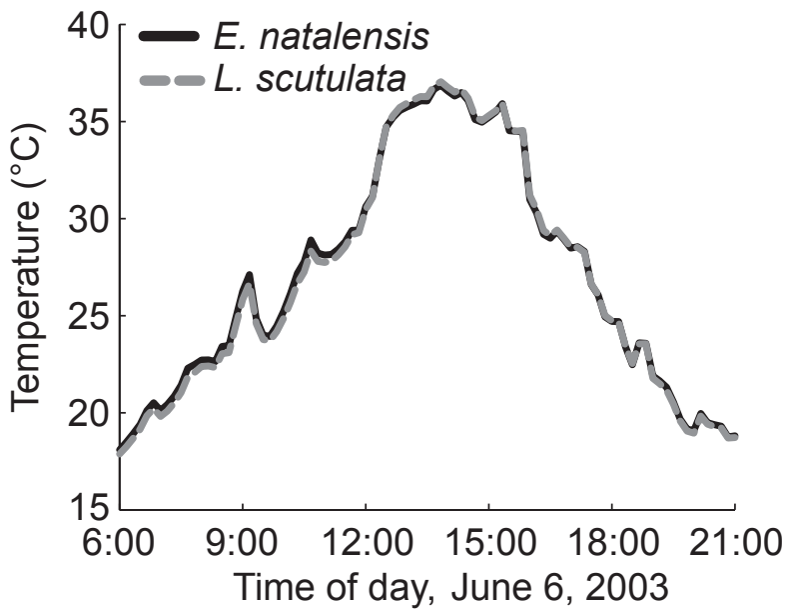

